\title{
The landscape of bispecific T cell engager in cancer treatment
}

\author{
Shujie Zhou ${ }^{1,2}$, Mingguo Liư ${ }^{3}$ Fei Ren ${ }^{2}$, Xiangjiao Meng ${ }^{1,2,4^{*}}$ and Jinming $\mathrm{Yu}^{1,2}$
}

\begin{abstract}
T cell-based immunotherapies have revolutionized treatment paradigms in various cancers, however, limited response rates secondary to lack of significant T-cell infiltration in the tumor site remain a major problem. To address this limitation, strategies for redirecting $T$ cells to treat cancer are being intensively investigated, while the bispecific $T$ cell engager (BiTE) therapy constitutes one of the most promising therapeutic approaches. BiTE is a bispecific antibody construct with a unique function, simultaneously binding an antigen on tumor cells and a surface molecule on $T$ cells to induce tumor lysis. BiTE therapy represented by blinatumomab has achieved impressive efficacy in the treatment of B cell malignancies. However, major mechanisms of resistance to BiTE therapy are associated with antigen loss and immunosuppressive factors such as the upregulation of immune checkpoints. Thus, modification of antibody constructs and searching for combination strategies designed to further enhance treatment efficacy as well as reduce toxicity has become an urgent issue, especially for solid tumors in which response to BiTE therapy is always poor. In particular, immunotherapies focusing on innate immunity have attracted increasing interest and have shown promising antitumor activity by engaging innate cells or innate-like cells, which can be used alone or complement current therapies. In this review, we depict the landscape of BiTE therapy, including clinical advances with potential response predictors, challenges of treatment toxicity and resistance, and developments of novel immune cell-based engager therapy.
\end{abstract}

Keywords: Immunotherapy, Bispecific T cell engager, Cancer

\section{Introduction}

$\mathrm{T}$ cell-based cancer immunotherapies have transformed the clinical practice of cancer treatment by targeting and mobilizing $\mathrm{T}$ cells to eradicate malignant cells. Depending on the mechanisms of action, $\mathrm{T}$ cell-based cancer immunotherapies can be mainly divided into two classes: one against immunosuppressive factors represented by immune checkpoint inhibitors (ICIs), the other one focusing on immunostimulatory pathways represented by chimeric antigen receptor (CAR) $\mathrm{T}$ cells and T-cell engaging bispecific antibodies (bsAbs) [1-3]. ICIs have revolutionized cancer treatment in the clinic, especially in

\footnotetext{
* Correspondence: mengxiangjiao@126.com

${ }^{1}$ Cheeloo College of Medicine, Shandong University, Jinan, Shandong, China ${ }^{2}$ Department of Radiation Oncology, Shandong Cancer Hospital affiliated to Shandong First Medical University, Jinan, Shandong, China

Full list of author information is available at the end of the article
}

several advanced solid tumors, for instance, melanoma and non-small-cell lung cancer [4-7]. They hamper the tumor immune escape by blocking key immunosuppressive molecules such as programmed cell death 1 (PD-1) and its ligand (PD-L1) and releasing the "brake" of cytotoxic $\mathrm{T}$ cells to eliminate tumor cells, however, response rates of ICIs remain limited [8]. A major reason for this is the lack of a sufficient number of tumor-infiltrating immune cells (TILs), primarily $\mathrm{T}$ cells, in the tumor site, which is referred to as exhibiting cold phenotype [9]. CAR T-cell therapy is a newly developed adoptive cell therapy by genetically engineering $\mathrm{T}$ cells to express a CAR comprising intracellular $\mathrm{T}$-cell signaling domains and an extracellular antigen-recognition structure targeting tumor-associated antigens (TAAs), redirecting and activating $\mathrm{T}$ cells to eradicate malignant cells specifically [10]. The preparation of CAR T Cells primarily includes

(c) The Author(s). 2021 Open Access This article is licensed under a Creative Commons Attribution 4.0 International License, which permits use, sharing, adaptation, distribution and reproduction in any medium or format, as long as you give appropriate credit to the original author(s) and the source, provide a link to the Creative Commons licence, and indicate if changes were made. The images or other third party material in this article are included in the article's Creative Commons licence, unless indicated otherwise in a credit line to the material. If material is not included in the article's Creative Commons licence and your intended use is not permitted by statutory regulation or exceeds the permitted use, you will need to obtain permission directly from the copyright holder. To view a copy of this licence, visit http://creativecommons.org/licenses/by/4.0/ The Creative Commons Public Domain Dedication waiver (http://creativecommons.org/publicdomain/zero/1.0/) applies to the data made available in this article, unless otherwise stated in a credit line to the data. 
isolation of $\mathrm{T}$ cells from patients, genetic modification of $\mathrm{T}$ cells, expansion of $\mathrm{T}$ cells in vitro, and infusion of edited $\mathrm{T}$ cells to patients, however, which is a complex and time-consuming process [11]. The other alternative approach to redirect $\mathrm{T}$ cells against target cells is $\mathrm{T}$-cell engaging bsAbs with unique function engaging TAAs on cancer cells and cell surface molecules on T cells. Bispecific $\mathrm{T}$-cell engager (BiTE) stands out as a novel subclass of T-cell engaging bsAbs with promising clinical results in the treatment of cancers. And the comparison of these three $\mathrm{T}$-cell based immunotherapies is summarized in Table 1.

\section{BiTE design and mechanism of action}

In general, human antibodies are monospecific that usually recognize only one targeted antigen. bsAbs simultaneously target two different antigens for cancer treatment via redirecting immune cells to tumor cells, delivering drugs to tumors, and blocking two biological pathways significant for tumors [12]. Among them, redirecting immune cells, primarily $\mathrm{T}$ cells, to target cells is the most successful and widely used function to induce specific and powerful anti-tumor activity. Due to the invariant property of CD3 chains in the T cell receptor (TCR), CD3 is always selected as a cell surface target [13]. Thus, numerous bsAbs targeting CD3 are developed in a variety of different constructs, they can be broadly classified into two categories: bsAbs with Fc domains and bsAbs without Fc domains. Fc domains contribute to the maintenance of stability, simplification of the purification process, and extending of half-life for bsAbs [14]. However, the interaction between Fc domains and their receptors on various types of immune effector cells such as natural killer (NK) cells, monocytes, and macrophages, is capable of inducing antibody-dependent cell-mediated cytotoxicity (ADCC), while Fc domains can also bind complement to elicit complement-dependent cytotoxicity (CDC), leading to the unnecessary non-specific immune response during bsAbs treatment [15]. BiTE falls into the latter category with a small molecular size. Two single-chain variable fragments (scFvs) from an anti-TAA and an anti-CD3 monoclonal antibody, respectively, form the canonical BiTE molecule with a short linker connecting them in tandem [16]. scFvs consisting of heavy chain variable regions $(\mathrm{VH})$ and light chain variable regions (VL) of immunoglobulin (Ig) are commonly used as antigen-binding domains (Fig. 1). Therefore, BiTE is a small and flexible molecule, which is easily diffusible and can quickly move from the site of administration to the site of lesions, redirecting cytotoxic $\mathrm{T}$ cells to cancer cells with high affinity.

Generally, TAAs are presented by major histocompatibility complex (MHC) molecules expressed on tumor

Table 1 Comparison of three main T cell-based immunotherapies: ICl, CAR T cell, and BiTE

\begin{tabular}{|c|c|c|c|}
\hline & $\mathrm{ICI}$ & CAR-T cell & BiTE \\
\hline Structure & $\begin{array}{l}\text { Monoclonal antibody targeting } \\
\text { immune checkpoint proteins }\end{array}$ & $\begin{array}{l}\text { A T cell from patients that are genetically re- } \\
\text { engineered to present a synthetic transmem- } \\
\text { brane receptor on the surface to target a tumor } \\
\text { antigen on tumor cells }\end{array}$ & $\begin{array}{l}\text { A recombinant antibody comprised of two } \\
\text { tandem } \mathrm{scFv} \text {, one binding CD3 on T cells, } \\
\text { the other targeting a tumor antigen on } \\
\text { tumor cells }\end{array}$ \\
\hline $\begin{array}{l}\text { Anti-tumor } \\
\text { mechanisms }\end{array}$ & $\begin{array}{l}\text { Blocking the inhibitory immune } \\
\text { checkpoint proteins that result in } \\
\text { cytotoxic T cell-mediated immune } \\
\text { response }\end{array}$ & $\begin{array}{l}\text { Inducing tumor cell lysis by the formation of } \\
\text { immune synapse between T cells and tumor } \\
\text { cells }\end{array}$ & $\begin{array}{l}\text { Inducing tumor cell lysis by the formation of } \\
\text { immune synapse between T cells and tumor } \\
\text { cells }\end{array}$ \\
\hline $\begin{array}{l}\text { Recruitment } \\
\text { of T cells }\end{array}$ & $\begin{array}{l}\text { Passive, acting on tumor-infiltrating } \\
\text { and endogenous T cells to kill tumor } \\
\text { cells }\end{array}$ & $\begin{array}{l}\text { Active, redirecting engineered T cells outside of } \\
\text { body to kill tumor cells }\end{array}$ & $\begin{array}{l}\text { Passive, dependent on endogenous T cells } \\
\text { and redirecting them to kill tumor cells }\end{array}$ \\
\hline Production & $\begin{array}{l}\text { Hybridoma technology, pervasive for } \\
\text { all patients }\end{array}$ & $\begin{array}{l}\text { Genetically engineering patient's T cells outside } \\
\text { of body, individualized for each patient }\end{array}$ & $\begin{array}{l}\text { Genetically engineered and purified from } \\
\text { mammalian cell lines, pervasive for all } \\
\text { patients }\end{array}$ \\
\hline Indications & $\begin{array}{l}\text { Mainly in solid tumors with approval } \\
\text { in a small part of hematologic } \\
\text { neoplasms }\end{array}$ & All in hematologic neoplasms & $\begin{array}{l}\text { All in hematologic neoplasms but with } \\
\text { promising results for solid tumors }\end{array}$ \\
\hline Toxicity & $\begin{array}{l}\text { Immune-mediated AEs such as } \\
\text { hyperactivation and hypersensitivity }\end{array}$ & On-target off-tumor effects, CRS, neurotoxicity & $\begin{array}{l}\text { On-target off-tumor effects, CRS, } \\
\text { neurotoxicity }\end{array}$ \\
\hline Advantages & $\begin{array}{l}\text { Broad-spectrum anti-tumor activity, } \\
\text { easy production }\end{array}$ & $\begin{array}{l}\text { MHC-independent, TCR-independent, endogen- } \\
\text { ous T cell-independent }\end{array}$ & $\begin{array}{l}\text { MHC-independent, TCR-independent, rela- } \\
\text { tively easy production, tumor-infiltrating T } \\
\text { cell-independent }\end{array}$ \\
\hline Disadvantages & $\begin{array}{l}\text { Tumor-infiltrating T cell-dependent, } \\
\text { immune checkpoint expression- } \\
\text { dependent, MHC-dependent, TCR- } \\
\text { dependent }\end{array}$ & $\begin{array}{l}\text { Lack of efficacy for solid tumors, long-term and } \\
\text { complex production, antigen-dependent }\end{array}$ & $\begin{array}{l}\text { Antigen-dependent, continuous } \\
\text { administration due to a short half-life }\end{array}$ \\
\hline
\end{tabular}




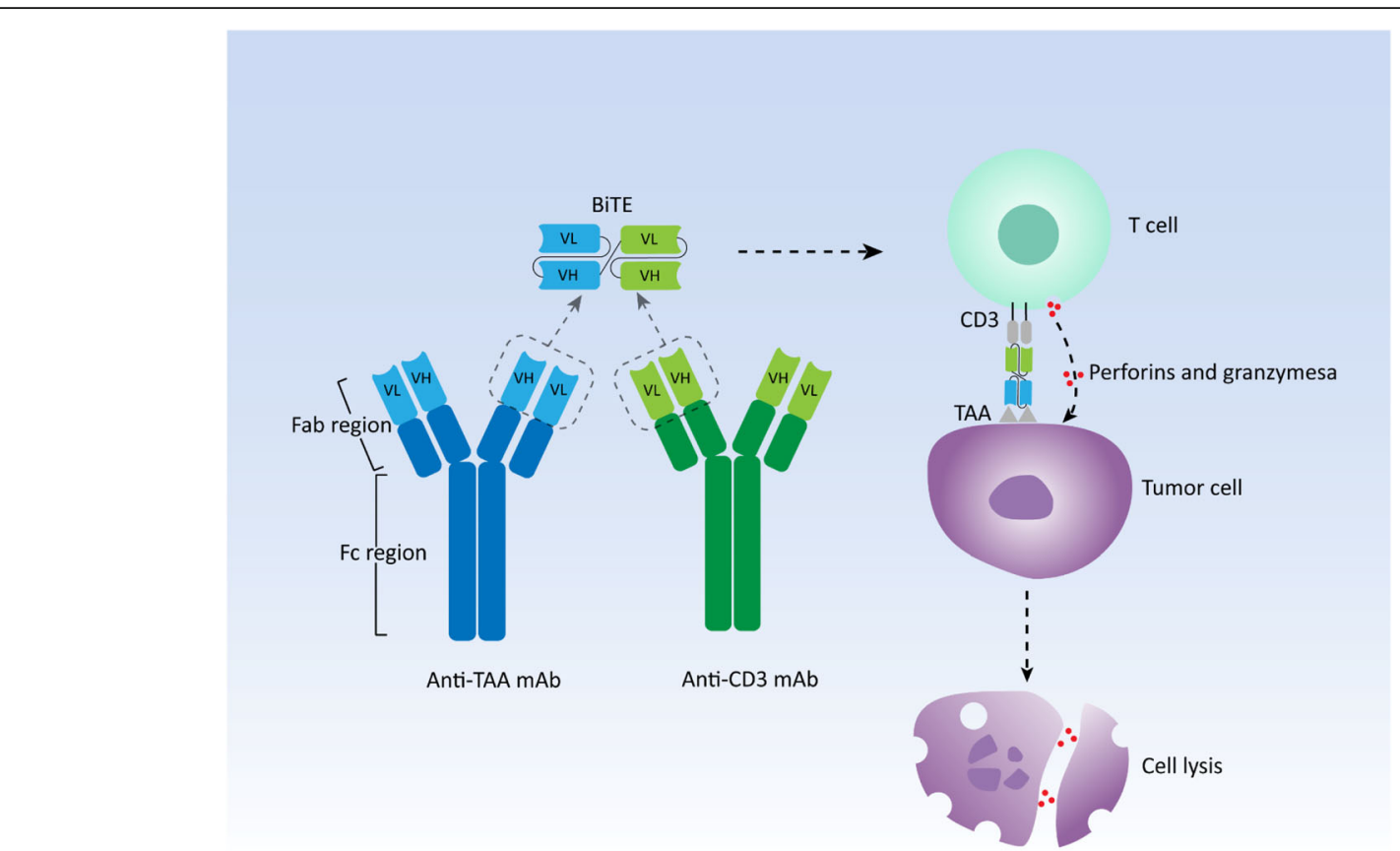

Fig. 1 The schematic representation of structure and mechanism of action of canonical bispecific T-cell engager (BiTE). mAb: Monoclonal antibody; VH: Heavy chain variable region; VL: Light chain variable region; TAA: Tumor-associated antigen

cells, interacting with TCR on T cells and inducing Tcell activation to eliminate malignant cells, which are known as MHC restriction. However, the impairment or loss of the ability to present antigens for MHC molecules is one of the reasons for the intrinsic resistance to immunotherapies such as ICI therapy [17-19]. Moreover, effective T-cell activation and immune response also require costimulatory signals, primarily CD28 signals [20]. Nevertheless, BiTE can crosslink cytotoxic T cells and cancer cells independently from MHC restriction as well as costimulatory signals like a bridge, and then these $\mathrm{T}$ cells are activated and start to proliferate, inducing the formation of the immunologic synapse [21-23]. Perforins and granzymes are secreted by these activated $\mathrm{T}$ cells at the site of the immunologic synapse, which results in the cytotoxic lysis of target cells [24]. Compared with other bsAbs and monoclonal IgG antibodies, in cellular models, BiTE has a $100 \sim 10,000$ fold higher efficacy in tumor cell lysis with a low ratio of $\mathrm{T}$ cells to target tumor cells [25]. In addition, BiTE can be produced by mammalian cell lines in large quantities, resulting in a relatively simple and fast production process compared with the lengthy and complicated culture of CAR T cells [16]. In the next section, we will present the latest clinical advances of BiTE therapy with published results in both hematologic neoplasms and solid tumors.

\section{Clinical advances of BiTE in hematological malignancies}

A primary requirement for successful BiTE therapy is the identification of appropriate TAAs expressed on target cells other than normal cells to avoid on-target/off-tumor toxicity. Abnormal expression of CD19 can be observed in many hematologic malignancies associated with $\mathrm{B}$ cells, contributing to tumorigenesis, besides, expression of CD19 is restricted to malignant and normal B-lineage cells [26-28]. Thus, CD19 is an attractive target for immunotherapies against B-cell malignancies. Blinatumomab is the first-in-class CD19 $\times$ CD3 canonical BiTE construct with a low molecular weight of $55 \mathrm{kDa}$. While adults with newly diagnosed B-cell precursor acute lymphoblastic leukemia (B-ALL) have achieved a complete remission (CR) rate of $80-90 \%$ with chemotherapy [29], patients with relapsed or refractory $(\mathrm{R} / \mathrm{R})$ disease, the cytogenetic abnormality with Philadelphia $(\mathrm{Ph})$ chromosome and the minimal residual disease (MRD) after initial therapy remain major challenges and are associated with poor prognosis. Moreover, R/R non-Hodgkin lymphoma (NHL) that most frequently originate from $B$ cells is another challenge in treating patients with B-cell malignancies. Nevertheless, blinatumomab has demonstrated remarkable clinical efficacy in addressing these thorny issues, which is summarized by other recent reviews [3, 30, 31] (Table 2). Blinatumomab has been approved by FDA for the treatment of both children and adults with R/R B-ALL and 
gained accelerated approval to treat patients with MRDpositive B-ALL, which is the first and only BiTE antibody reaching the market. A phase 1 clinical trial evaluating next-generation BiTE with extended half-life (HLE) AMG 562 is ongoing in patients with R/R NHL (NCT03571828). Other main T-cell engaging bsAbs targeting CD19 and CD3 include TNB-486 [48], dual affinity retargeting antibody (DART) duvortuxizumab [49], and tandem diabody (TandAb) AFM11 [50] developed for B-cell malignancies. However, clinical trials for DART duvortuxizumab and TandAb AFM11 were discontinued due to severe toxicity during treatment.

CD33 mediates the proliferation and differentiation of myeloid cells and it can be detected on the malignant myeloid blasts in the majority of patients with acute myeloid leukemia (AML), suggesting it is a potential target for cancer immunotherapy [51]. In 2020 ASCO, updated data from an ongoing phase 1 study (NCT02520427) conducted for AMG 330, a CD33 $\times$ CD3 canonical BiTE antibody, has been reported. AMG 330 was given at doses ranging from $0.5-720 \mu \mathrm{g} / \mathrm{d}$ in the manner of continuous IV infusion among 55 patients with R/R AML. The most common treatment-related AEs was cytokine release syndrome (CRS) with a grade $\geq 3$ CRS rate of $13 \%$. CRS was reversible and was associated with the dose level and leukemic burden at baseline. Among 42 patients evaluable for response, there were $3 \mathrm{CR}$ and 4 complete remission with incomplete hematological recovery (CRi) observed at the dose of $\geq 120 \mu \mathrm{g} / \mathrm{d}$ [52]. In addition, preliminary results from an ongoing phase 1clincal trial (NCT03224819) have shown anti-leukemic activity of HLE-BiTE AMG 673 in the treatment of R/R AML [53]. Currently, other main anti-CD33 $\mathrm{T}$-cell engaging bsAbs have entered clinical development and are in phase 1 clinical study in patients with R/R AML, including JNJ-67571244 [54], affinitytailored adaptors for T-cells (ATAC) GEM333 [55], and TandAb AMV 564 [56].

B-cell maturation antigen (BCMA) essential for the long-term survival of plasma cells is highly expressed on the malignant plasma cells in multiple myeloma (MM) with almost no expression on normal cells, which can be the promising target for $\mathrm{T}$-cell based immunotherapy [57]. A first-in-human clinical trial recently demonstrated favorable efficacy and low toxicity of AMG 420, an anti-BCMA canonical BiTE molecule, treating patients with R/R MM. Forty-two patients who had previously been treated with more than 2 lines of therapies were enrolled and received 6-week cycles of AMG 420 at the dose of $0.2-800 \mu \mathrm{g} / \mathrm{d}$. Among 10 patients in the maximum tolerated dose (MTD) cohort at the dose of $400 \mu \mathrm{g} / \mathrm{d}$, the overall response rate (ORR) was $70 \%$ with 5 MRD-negative CR, 1 very good partial response (VGPR), and 1 PR. The serious AEs rate was $48 \%$, of these, infections were the most common with a rate of
$33 \%$. The incidence of grade $\geq 3$ CRS was $2 \%$ with no grade $\geq 3$ central nervous system (CNS) toxicity [58]. AMG 420 has already been fast-tracked for development by the FDA. In addition, the second-generation HLEBiTE AMG 701 has achieved an 83\% ORR in patients with $\mathrm{R} / \mathrm{R} \mathrm{MM}$, the majority of responders experienced triple therapy failure [59]. Teclistamab [60], REGN5458 [61], CC-93269 [62] PF-06863135 [63], and TNB-383B [64] are other investigational T-cell engaging bsAbs designed to bind to BCMA with structural differences, all of them have entered the early clinical stage for treating patients with $\mathrm{R} / \mathrm{R}$ MM with promising efficacy. The clinical advances of these newly developed BiTE antibodies and other T-cell engaging bsAbs are summarized in Table 3.

\section{Clinical advances of BiTE in solid tumors}

Given the favorable results of BiTE therapy in hematological malignancies, numerous BiTE antibodies targeting TAAs expressed on solid tumors are currently in clinical development (Table 4). Prostate-specific membrane antigen (PSMA) belongs to the type II transmembrane protein family highly confined to the prostate tissues. It is overexpressed in most prostate cancer (PC) and can be used as an ideal tumor antigen target [76]. Pasotuxizumab (AMG 212) is a canonical BiTE antibody targeting PSMA [77]. The anti-tumor activity which was defined by PSA level decrease was dose-dependent. Two patients achieved long-term PSA responses with more than 1 year of treatment at doses of $40 \mu \mathrm{g} / \mathrm{d}$ and $80 \mu \mathrm{g} / \mathrm{d}$, respectively. The grade 3 AEs occurred in $81 \%$ of patients and the most common of them were decreased lymphocytes (44\%) and infections (44\%). Treatmentrelated SAE was observed in only one patient (fatigue). This is the first clinical study supporting BiTE immunotherapy's role as an effective intervention in the treatment of patients with solid tumors. Moreover, in 2020 ESMO, HLE-BiTE AMG 160 has demonstrated a safety profile and showed evidence of preliminary efficacy in patients with mCRPC [78]. Another PSMA-targeting Tcell engager HPN424 has also entered a phase 1 clinical trial with early signs of clinical activity in patients with mCRPC [79].

AMG 596 is a canonical BiTE molecule targeting the class III variant of the epidermal growth factor receptor (EGFRvIII). EGFR is a transmembrane cell surface receptor frequently overexpressed in patients with glioblastoma (GBM) that contributes to the formation of the tumor, meanwhile, EGFRvIII is the most common EGFR mutation in EGFR-positive patients with GBM [92]. Interim analysis of a phase 1 study (NCT03296696) evaluating the safety and efficacy of AMG 596 against recurrent GBM has shown 1 PR (12.5\%) and 2 SD (25\%) in 8 patients with sufficient follow-up. Among 14 
Table 2 Clinical advances of blinatumomab in the treatment of B-cell malignancies

\begin{tabular}{|c|c|c|c|c|c|c|c|}
\hline $\begin{array}{l}\text { Study/NCT } \\
\text { identifier }\end{array}$ & Phase & Indications & $\begin{array}{l}\text { Number of } \\
\text { patients }\end{array}$ & $\begin{array}{l}\text { Blinatumomab } \\
\text { dosing }\end{array}$ & Efficacy & Toxicity & Reference \\
\hline $\begin{array}{l}\text { GMALL (original } \\
\text { study } \\
\text { NCT00198991, } \\
\text { follow-up study } \\
\text { NCT00198978) }\end{array}$ & 2 & $\begin{array}{l}\text { Adults } \\
(\geq 18 \text { years }) \\
\text { with MRD- } \\
\text { positive B- } \\
\text { ALL }\end{array}$ & $\begin{array}{l}21 \text { ( } 20 \\
\text { evaluable for } \\
\text { response) }\end{array}$ & $\begin{array}{l}\text { Continuous IV } \\
\text { infusion at a dose of } \\
15 \mu \mathrm{g} / \mathrm{m}^{2} / \mathrm{d}\end{array}$ & $\begin{array}{l}\text { MRD-negative response rate: } 80 \% \\
\text { (16/20) 5-year RFS rate: } 50 \% \text { (10/ } \\
\text { 20) Median RFS: } 19.1 \text { months in } \\
16 \text { MRD responders; } 3.2 \text { months } \\
\text { in } 4 \text { nonresponders CR in HSCT } \\
\text { patients: } 5 / 9 \text { CR in non-HSCT pa- } \\
\text { tients: } 5 / 11\end{array}$ & $\begin{array}{l}\text { Grade } \geq 3 \text { AEs: } \\
81 \% \text { Grade } 3 \\
\text { CNS AEs: } 19 \%\end{array}$ & [32-34] \\
\hline $\begin{array}{l}\text { BLAST } \\
\text { (NCT01207388). }\end{array}$ & 2 & $\begin{array}{l}\text { Adults with } \\
\text { MRD- } \\
\text { positive B- } \\
\text { ALL }\end{array}$ & $\begin{array}{l}116 \text { (113 } \\
\text { evaluable for } \\
\text { response) }\end{array}$ & $\begin{array}{l}\text { Continuous IV } \\
\text { infusion at a dose of } \\
15 \mathrm{\mu g} / \mathrm{m}^{2} / \mathrm{d}\end{array}$ & $\begin{array}{l}\text { MRD-negative response rate: } 78 \% \\
\text { ( } 88 / 113) 18 \text { months RFS rate: } 54 \% \\
\text { Median RFS: } 18.9 \text { months Median } \\
\text { OS: } 36.5 \text { months } 25 \% \text { patients } \\
\text { without HSCT after } \\
\text { blinatumomab remained in } \\
\text { continuous CR } 49 \% \text { with HSCT } \\
\text { remained in continuous CR }\end{array}$ & $\begin{array}{l}\text { Grade } \geq 3 \text { AEs: } \\
60 \% \text { Any grade } \\
\text { CRS: } 3 \% \\
\text { Grade } \geq 3 \text { CRS: } \\
2 \% \text { Any grade } \\
\text { CNS AEs: } 53 \% \\
\text { Grade } \geq 3 \text { CNS } \\
\text { AEs: } 13 \%\end{array}$ & {$[35,36]$} \\
\hline NCT02412306 & $1 / 2$ & $\begin{array}{l}\text { Japanese } \\
\text { adults with } \\
\text { R/R Ph- } \\
\text { negative B- } \\
\text { ALL }\end{array}$ & 26 & $\begin{array}{l}\text { Continuous IV } \\
\text { infusion at a dose of } \\
9 \mu \mathrm{g} / \mathrm{m}^{2} / \mathrm{d} \text { for the } \\
\text { first } 7 \text { days and } \\
28 \mu \mathrm{g} / \mathrm{m}^{2} / \mathrm{d} \\
\text { thereafter }\end{array}$ & $\begin{array}{l}\text { Phase } 1 \text { b: } \\
\text { CR/CRh rate: } 80 \%(4 / 5) \\
\text { MRD-negative response rate in } \\
\text { responders: } 100 \%(4 / 4) \\
\text { Phase 2: } \\
\text { CR/CRh rate: } 38 \%(8 / 21) \\
\text { MRD-negative response rate in } \\
\text { responders: } 38 \%(3 / 8) \\
\text { Median RFS: } 5 \text { months }\end{array}$ & $\begin{array}{l}\text { Grade } \geq 3 \text { AEs: } \\
96 \% \\
\text { Any grade CRS: } \\
46 \% \\
\text { Grade } \geq 3 \text { CRS: } \\
4 \% \\
\text { Any grade CNS } \\
\text { AEs: } 46 \% \\
\text { Grade } \geq 3 \text { CNS } \\
\text { AEs: } 5 \%\end{array}$ & {$[37]$} \\
\hline NCT01209286 & 2 & $\begin{array}{l}\text { Adults with } \\
\text { R/R Ph- } \\
\text { negative B- } \\
\text { ALL }\end{array}$ & 36 & $\begin{array}{l}\text { Continuous IV } \\
\text { infusion at a dose of } \\
5-30 \mu \mathrm{g} / \mathrm{m}^{2} / \mathrm{d}\end{array}$ & $\begin{array}{l}\text { CR/CRh rate: } 69 \%(25 / 36) \text { MRD- } \\
\text { negative response rate in re- } \\
\text { sponders: } 88 \%(22 / 25) \text { Median } \\
\text { OS: } 9.8 \text { months Median RFS: } 7.6 \\
\text { months }\end{array}$ & $\begin{array}{l}\text { CNS AES } \\
\text { requiring } \\
\text { intervention: } \\
17 \% \\
\text { Grade } \geq 3 \text { CRS: } \\
6 \%\end{array}$ & [38] \\
\hline NCT01466179 & 2 & $\begin{array}{l}\text { Adults } \\
(\geq 18 \text { years) } \\
\text { with R/R } \\
\text { Ph- } \\
\text { negative B- } \\
\text { ALL }\end{array}$ & 189 & $\begin{array}{l}\text { Continuous IV } \\
\text { infusion from } 9 \text { to } \\
28 \mu \mathrm{g} / \mathrm{m}^{2} / \mathrm{d}\end{array}$ & $\begin{array}{l}\text { CR/CRh rate: } 43 \%(81 / 189) \text { MRD- } \\
\text { negative response rate in re- } \\
\text { sponders: } 82 \% \text { (60/73) Median } \\
\text { OS: } 6.1 \text { months Median RFS: } 5.9 \\
\text { months }\end{array}$ & $\begin{array}{l}\text { Grade } \geq 3 \text { AEs: } \\
83 \% \text { Grade } \geq 3 \\
\text { CRS: } 2 \% \\
\text { Any grade CNS } \\
\text { AEs: } 52 \% \\
\text { Grade } \geq 3 \text { CNS } \\
\text { AEs: } 13 \%\end{array}$ & [39] \\
\hline $\begin{array}{l}\text { TOWER } \\
\text { (NCT02013167) }\end{array}$ & 3 & $\begin{array}{l}\text { Adults } \\
(\geq 18 \text { years) } \\
\text { with R/R } \\
\text { Ph- } \\
\text { negative B- } \\
\text { ALL }\end{array}$ & $\begin{array}{l}405 \text { ( } 271 \text { for } \\
\text { blinatumomab, } \\
134 \text { for } \\
\text { chemotherapy) }\end{array}$ & $\begin{array}{l}\text { Continuous IV } \\
\text { infusion from } 9 \text { to } \\
28 \mu \mathrm{g} / \mathrm{m}^{2} / \mathrm{d}\end{array}$ & $\begin{array}{l}\text { Median OS: } 7.7 \text { vs. } 4.0 \text { months CR } \\
\text { rate: } 34 \% \text { vs. } 16 \% \text {; CR/CRh/CRi } \\
\text { rate: } 44 \% \text { vs. } 25 \% \text { 6-month EFS: } \\
31 \% \text { vs. } 12 \% \text { Median DOR: } 7.3 \text { vs. } \\
4.6 \text { months }\end{array}$ & $\begin{array}{l}\text { Grade } \geq 3 \text { AEs: } \\
87 \% \text { vs. } 92 \% \\
\text { Grade } \geq 3 \text { CNS } \\
\text { AEs: } 9.4 \% \\
\text { vs. } 8.3 \% \\
\text { Grade } \geq 3 \text { CRS: } \\
4.9 \% \text { vs. } 0 \% \\
\text { (blinatumomab } \\
\text { vs. } \\
\text { chemotherapy) }\end{array}$ & [40] \\
\hline $\begin{array}{l}\text { RIALTO } \\
\text { (NCT02187354) }\end{array}$ & $\begin{array}{l}\text { Expanded } \\
\text { Access }\end{array}$ & $\begin{array}{l}\text { Children } \\
\text { ( } \leq 17 \text { years) } \\
\text { with R/R B- } \\
\text { ALL }\end{array}$ & $\begin{array}{l}110 \text { ( } 98 \\
\text { evaluable for } \\
\text { response) }\end{array}$ & $\begin{array}{l}\leq 25 \% \text { blasts: } 15 \mu \mathrm{g} / \\
\mathrm{m}^{2} / \mathrm{d} \\
>25 \% \text { blasts: } 5 \mu \mathrm{g} / \\
\mathrm{m}^{2} / \mathrm{d} \text { for first } 7 \text { days, } \\
15 \mu \mathrm{g} / \mathrm{m}^{2} / \mathrm{d} \\
\text { thereafter, }\end{array}$ & $\begin{array}{l}\text { CR rate: } 59 \% \text { (58/98) } \\
\text { MRD-negative response rate in } \\
\text { responders: } 79 \% \text { (46/58) } \\
\text { Median OS: } 13.1 \text { months } \\
\text { Median RFS: } 8.5 \text { months } 62 \% \text { (36/ } \\
\text { 58) proceeded to HSCT after } \\
\text { achieving CR }\end{array}$ & $\begin{array}{l}\text { Grade } \geq 3 \text { AEs: } \\
65 \% \\
\text { Grade } \geq 3 \text { CRS: } \\
3 \% \\
\text { Any grade CNS } \\
\text { AEs: } 42 \% \\
\text { Grade } \geq 3 \text { CNS } \\
\text { AEs: } 5.5 \%\end{array}$ & [41] \\
\hline $\begin{array}{l}\text { MT103-205 } \\
\text { (NCT01471782) }\end{array}$ & $1 / 2$ & $\begin{array}{l}\text { Children } \\
\text { ( } \leq 17 \text { years) } \\
\text { with R/R B- } \\
\text { ALL }\end{array}$ & $\begin{array}{l}94 \text { (70 } \\
\text { evaluable for } \\
\text { response) }\end{array}$ & $\begin{array}{l}\text { Continuous IV } \\
\text { infusion from } 5 \text { to } \\
15 \mu \mathrm{g} / \mathrm{m}^{2} / \mathrm{d}\end{array}$ & $\begin{array}{l}\text { CR rate: } 39 \% \text { (27/70) MRD- } \\
\text { negative response rate in re- } \\
\text { sponders: } 52 \% \text { (14/27) 48\% (13/ } \\
\text { 27) proceeded to HSCT after } \\
\text { achieving CR }\end{array}$ & $\begin{array}{l}\text { Grade } \geq 3 \text { AEs: } \\
87 \% \\
\text { Any grade CRS: } \\
11 \% \\
\text { Grade } \geq 3 \text { CRS: } \\
6 \% \\
\text { Any grade CNS }\end{array}$ & {$[42]$} \\
\hline
\end{tabular}


Table 2 Clinical advances of blinatumomab in the treatment of B-cell malignancies (Continued)

\begin{tabular}{|c|c|c|c|c|c|c|c|}
\hline $\begin{array}{l}\text { Study/NCT } \\
\text { identifier }\end{array}$ & Phase & Indications & $\begin{array}{l}\text { Number of } \\
\text { patients }\end{array}$ & $\begin{array}{l}\text { Blinatumomab } \\
\text { dosing }\end{array}$ & Efficacy & Toxicity & Reference \\
\hline & & & & & & $\begin{array}{l}\text { AEs: } 24 \% \\
\text { Grade } \geq 3 \text { CNS } \\
\text { AEs: } 4 \%\end{array}$ & \\
\hline NCT02000427 & 2 & $\begin{array}{l}\text { Adults } \\
\text { ( } \geq 18 \text { years) } \\
\text { with R/R } \\
\text { Ph-positive } \\
\text { B-ALL }\end{array}$ & 45 & $\begin{array}{l}\text { Continuous IV } \\
\text { infusion from } 9 \text { to } \\
28 \mu \mathrm{g} / \mathrm{m}^{2} / \mathrm{d}\end{array}$ & $\begin{array}{l}\text { CR/CRh rate: } 36 \%(16 / 45) \text { MRD- } \\
\text { negative response rate in re- } \\
\text { sponders: } 88 \%(14 / 16) \text { Median } \\
\text { OS: } 7.1 \text { months Median RFS: } 6.7 \\
\text { months } 44 \% \text { ( } 7 / 16) \text { proceeded to } \\
\text { HSCT after achieving CR }\end{array}$ & $\begin{array}{l}\text { Grade } \geq 3 \text { AEs: } \\
82 \% \\
\text { Any grade CRS: } \\
7 \% \\
\text { Grade } \geq 3 \text { CNS } \\
\text { AEs: } 7 \%\end{array}$ & [43] \\
\hline $\begin{array}{l}\text { MT103-104 } \\
\text { (NCT00274742) }\end{array}$ & 1 & $\begin{array}{l}\text { Adults } \\
(\geq 18 \text { years) } \\
\text { with R/R B- } \\
\text { NHL }\end{array}$ & 76 & $\begin{array}{l}\text { Dose-escalation: } 0.5- \\
90 \mu \mathrm{g} / \mathrm{m}^{2} / \mathrm{d} \text { Dose- } \\
\text { expansion: } 60 \mu \mathrm{\mu g} / \mathrm{m}^{2} / \\
\mathrm{d}\end{array}$ & $\begin{array}{l}\text { Patients with dose of } 60 \mu \mathrm{g} / \mathrm{m} 2 / \mathrm{d} \text { : } \\
\text { ORR: } 69 \% \text { across NHL subtypes } \\
\text { and } 55 \% \text { for DLBCL } \\
\text { Median DOR: } 404 \text { days Median OS } \\
\text { in overall population: } 4.6 \text { years } \\
\text { Median OS in responders: } 7.7 \\
\text { years Median OS in } \\
\text { nonresponders: } 1.1 \text { years }\end{array}$ & $\begin{array}{l}\text { Grade } 3,4 \text {, and } \\
5 \text { AEs: } 90,66, \\
\text { and } 4 \% \\
\text { respectively } \\
\text { Any grade CNS } \\
\text { AEs: } 71 \% \text { Grade } \\
3 \text { CNS AEs: } 22 \%\end{array}$ & {$[44,45]$} \\
\hline NCT02910063 & 2 & $\begin{array}{l}\text { Adults with } \\
\text { R/R B-NHL }\end{array}$ & 41 & $\begin{array}{l}\text { Continuous IV } \\
\text { infusion from } 9 \text { to } 28 \\
\text { to } 112 \mu \mathrm{g} / \mathrm{d}\end{array}$ & $\begin{array}{l}\text { ORR: } 37 \% \text { (15/41) including CMR: } \\
22 \%(9 / 41) \text { and PMR: } 15 \%(6 / 41) \\
\text { HSCT was performed in 53.3\% (8/ } \\
\text { 15) responders. }\end{array}$ & $\begin{array}{l}\text { Grade } \geq 3 \text { AEs: } \\
71 \% \\
\text { Grade } \geq 3 \text { CRS: } \\
2 \% \\
\text { Any grade CNS } \\
\text { AEs: } 56 \% \\
\text { Grade } \geq 3 \text { CNS } \\
\text { AEs.: } 24 \%\end{array}$ & {$[46]$} \\
\hline NCT01741792 & 2 & $\begin{array}{l}\text { Adults with } \\
\text { R/R B- } \\
\text { DLBCL }\end{array}$ & $\begin{array}{l}25 \text { ( } 21 \\
\text { evaluable for } \\
\text { response) }\end{array}$ & $\begin{array}{l}\text { Cohort I + III: } \\
\text { Stepwise dose } 9 \text { to } \\
28 \text { to } 112 \mu \mathrm{g} / \mathrm{d} \\
\text { Cohort II: Flat dose } \\
112 \mu \mathrm{g} / \mathrm{d}\end{array}$ & $\begin{array}{l}\text { Patients with dose of } 112 \mu \mathrm{g} / \mathrm{d} \text { at } \\
\text { least } 1 \text { week: } \\
\text { ORR: } 43 \%(9 / 21) \\
\text { CR rate: } 19 \%(4 / 21)\end{array}$ & $\begin{array}{l}\text { Cohort I: } n=23 \\
\text { Grade } \geq 3 \text { AEs: } \\
95.7 \% \\
\text { Any grade CRS: } \\
0 \% \text { Grade } \geq 3 \\
\text { CNS AEs: } 22 \% \\
\text { Cohort II: } n=2 \\
\text { Grade } \geq 3 \text { CNS } \\
\text { AEs: } 100 \%\end{array}$ & {$[47]$} \\
\hline
\end{tabular}

MRD Minimal residual disease, B-ALL B-precursor acute lymphoblastic leukemia, IV Intravenous, HSCT Allogeneic hematopoietic stem cell transportation, AEs Adverse events, $R / R$ Refractory/relapsed, $C R S$ Cytokine release syndrome, OS Overall survival, $R F S$ Relapse-free survival, $C R$ Complete remission, $C R h$ Complete remission with partial hematologic recovery, $C R i$ Complete remission with incomplete hematological recovery, Ph Philadelphia chromosome, NHL Non- Hodgkin lymphoma, $D L B C L$ Diffuse large B cell lymphoma, DLT Dose-limiting toxicity, DOR Duration of remission, EFS Event-free survival, ORR Objective response rate, CMR Complete metabolic response

evaluable patients, serious AEs occurred in $50 \%$ of patients, the most common treatment-related grade $\geq 3$ AEs were headache and depressed consciousness (both 14.3\%) [80].

Delta-like ligand 3 (DLL3) is particularly upregulated in small cell lung cancer (SCLC) but with minimal normal tissue expression. In 2020 the society for immunotherapy of cancer (SITC), preliminary results from an ongoing phase 1 study (NCT03319940) has demonstrated anti-tumor activity of AMG 757, a DLL3targeting HLE-BiTE, in patients with R/R SCLC with tolerable toxicity [81]. Among 38 evaluable patients, there were $6 \mathrm{PR}, 11 \mathrm{SD}$, and 1 unconfirmed PR. With a median follow-up of 8.8 months, five of the six responses were still in duration. The most common treatmentrelated AE was CRS with a rate of $43 \%$ and all CRS events were grade 1 or 2.

Additionally, AMG 199 [82] targeting mucin-17 (MUC17) and AMG 910 [83] targeting claudin18.2
(CLDN18.2) in patients with gastric cancer are in phase 1 clinical trials of NCT04117958 and NCT04260191, respectively.

\section{Predictors of response to BiTE therapy}

Blinatumomab represents BiTE therapy because it the only one approved for clinical use with the most outcome data. Some studies have reported that the high disease burden defined as $\geq 50 \%$ bone-marrow blasts was associated with the lower response rate of blinatumomab in the treatment of R/R B-ALL [39, 40, 42, 93]. For instance, in the phase 3 study, the remission rate including $\mathrm{CR}$ with full, partial, or incomplete hematologic recovery was $65.5 \%$ in R/R B-ALL patients with less than $50 \%$ of bone-marrow blasts, whereas it was only $34.4 \%$ for $\geq 50 \%$ [40]. A recent statistical study confirmed the negative correlation between disease burden and treatment response was statistically significant in R/R B-ALL patients treated with blinatumomab $(P=0.039)$ [94]. Moreover, 
Table 3 Clinical advances with promising published results in other BiTE and T-cell engaging bsAbs

\begin{tabular}{|c|c|c|c|c|c|c|c|c|}
\hline $\begin{array}{l}\text { NCT } \\
\text { identifier }\end{array}$ & Phase & Indications & $\begin{array}{l}\text { Number } \\
\text { of } \\
\text { patients }\end{array}$ & Drug & Format & Target & Results & Reference \\
\hline NCT03625037 & $1 / 2$ & R/R B-NHL & 67 & Epcoritamab & $\begin{array}{l}\text { Fully human IgG1-based } \\
\text { bsAb }\end{array}$ & $\begin{array}{l}\text { CD20/ } \\
\text { CD3 }\end{array}$ & $\begin{array}{l}\text { In DLBCL } \geq 12 \mathrm{mg}(n=18) \\
\text { ORR: } 66.7 \%(6 \mathrm{CRs}) \\
\text { In FL } \geq 0.76 \mathrm{mg}(n=8) \\
\text { ORR:100\% (2CRs) } \\
\text { In MCL ( } n=4) \\
\text { ORR: } 50 \%(1 \mathrm{CR}, 1 \mathrm{PR})\end{array}$ & [65] \\
\hline NCT02290951 & 1 & $\mathrm{R} / \mathrm{R}$ B-NHL & 127 & Odronextamab & $\begin{array}{l}\text { Fully human IgG4-based } \\
\text { bsAb }\end{array}$ & $\begin{array}{l}\text { CD20/ } \\
\text { CD3 }\end{array}$ & $\begin{array}{l}\text { In FL } \geq 5 \mathrm{mg}(n=28) \text {, } \\
\text { ORR: } 92.9 \% \text { (CR rate: } 75.0 \%) \text { In } \\
\text { DLBCL without prior CAR T } \\
\text { therapy } \geq 80 \mathrm{mg}(n=10) \text {, } \\
\text { ORR: } 60 \% \text { (CR rate: } 60 \%) \\
\text { In DLBCL with prior CAR T } \\
\text { therapy } \geq 80 \text { mg }(n=21) \text {, } \\
\text { ORR: } 33.3 \% \text { (CR rate: } 23.8 \%)\end{array}$ & [66] \\
\hline NCT02500407 & 1 & $\mathrm{R} / \mathrm{R} \mathrm{FL}$ & 62 & Mosunetuzumab & $\begin{array}{l}\text { Fully humanized } \lg G 1- \\
\text { based bsAb }\end{array}$ & $\begin{array}{l}\text { CD20/ } \\
\text { CD3 }\end{array}$ & $\begin{array}{l}\text { ORR: } 68 \% \text { (CR rate: } 50 \%, \text { PR rate: } \\
18 \% \text { ) }\end{array}$ & {$[67]$} \\
\hline NCT02924402 & 1 & $\begin{array}{l}\mathrm{R} / \mathrm{R} \mathrm{NHL} \\
\text { and CLL }\end{array}$ & 44 & XmAb13676 & Fully humanized bsAb & $\begin{array}{l}\text { CD20/ } \\
\text { CD3 }\end{array}$ & $\begin{array}{l}\text { In NHL } 80-125 \mu \mathrm{g} / \mathrm{kg}(n=18) \text {, } \\
\text { ORR: } 33.3 \% \\
\text { In CLL } 20 \mu \mathrm{g} / \mathrm{kg}(n=5) \text { : } \\
\text { ORR: } 25 \%\end{array}$ & [68] \\
\hline NCT03075696 & 1 & R/R NHL & 38 & Glofitamab & $\begin{array}{l}\text { Fully humanized lgG1- } \\
\text { based bsAb with a 2:1 } \\
\text { molecular format }\end{array}$ & $\begin{array}{l}\text { CD20/ } \\
\text { CD3 }\end{array}$ & $\begin{array}{l}\text { ORR: } 62.5 \% \text {, CMR rate: } 40.6 \% \text { In } \\
\text { aNHL }(n=24) \text {, } \\
\text { ORR: } 50.0 \% \text {, CMR rate: } 29.2 \% \text {. In } \\
\text { iNHL }(n=8) \text {, } \\
\text { ORR: } 100.0 \% \text {, CMR rate: } 75.0 \%\end{array}$ & [69] \\
\hline NCT04082936 & 1 & R/R NHL & 14 & IGM-2323 & $\begin{array}{l}\text { Fully humanized IgM- } \\
\text { based bsAb }\end{array}$ & $\begin{array}{l}\text { CD20/ } \\
\text { CD3 }\end{array}$ & $\begin{array}{l}\text { Tumor size reduction rate: } 64 \% \\
\text { (2 PRs) }\end{array}$ & [70] \\
\hline NCT02520427 & 1 & R/R AML & 55 & AMG 330 & Two tandem scFvs & $\begin{array}{l}\text { CD33/ } \\
\text { CD3 }\end{array}$ & $\begin{array}{l}\text { ORR: } 19 \% \text { (CR rate: } 7 \% \text {, CRi rate: } \\
\text { 10\%) }\end{array}$ & [52] \\
\hline NCT03224819 & 1 & $\mathrm{R} / \mathrm{R} \mathrm{AML}$ & 30 & AMG 673 & $\begin{array}{l}\text { Two tandem scFvs with } \\
\text { Fc region }\end{array}$ & $\begin{array}{l}\text { CD33/ } \\
\text { CD3 }\end{array}$ & $\begin{array}{l}\text { Decrease in blasts in bome } \\
\text { marrow rate: } 44 \%\end{array}$ & [53] \\
\hline NCT02514239 & 1 & R/R MM & 42 & AMG 420 & Two tandem scFvs & $\begin{array}{l}\mathrm{BCMA} / \\
\mathrm{CD} 3\end{array}$ & $\begin{array}{l}\text { ORR: } 31 \% \\
\text { At dose of } 400 \mathrm{mg} / \mathrm{d}(\mathrm{n}=10) \text {, } \\
\text { ORR: } 70 \% \text { ( } 5 \mathrm{MRD} \text {-negative CRs, } \\
1 \text { PR, and } 1 \text { VGPR) }\end{array}$ & {$[58]$} \\
\hline NCT03287908 & 1 & $\mathrm{R} / \mathrm{R} \mathrm{MM}$ & 75 & AMG 701 & $\begin{array}{l}\text { Two tandem scFvs with } \\
\text { Fc region }\end{array}$ & $\begin{array}{l}\text { BCMA } \\
\text { CD3 }\end{array}$ & $\begin{array}{l}\text { At the dose of } 3-12 \mathrm{mg}(n=45) \text {, } \\
\text { ORR: } 36 \% \text {; } \\
\text { At the dose of the } 9 \mathrm{mg}(n=6) \text {, } \\
\text { ORR: } 83 \% \text { (3PRs, 2VGPRs) }\end{array}$ & [59] \\
\hline NCT03145181 & 1 & R/R MM & 128 & Teclistamab & $\begin{array}{l}\text { Fully humanized IgG1- } \\
\text { based bsAb }\end{array}$ & $\begin{array}{l}\mathrm{BCMA} / \\
\mathrm{CD} 3\end{array}$ & $\begin{array}{l}\text { At the dose of } 1500 \mu \mathrm{g} / \mathrm{kg} \mathrm{sC} \\
(n=22) \text {, } \\
\text { ORR: } 73 \% \text { ( } \geq \text { CR rate: } 23 \% \\
\text { and } \geq \text { VGPR rate: } 55 \%)\end{array}$ & [71] \\
\hline NCT03761108 & 1 & $\mathrm{R} / \mathrm{R} \mathrm{MM}$ & 49 & REGN5458 & $\begin{array}{l}\text { Fully humanized lgG1- } \\
\text { based bsAb }\end{array}$ & $\begin{array}{l}\mathrm{BCMA} / \\
\mathrm{CD} 3\end{array}$ & $\begin{array}{l}\text { At the dose of } 96 \mathrm{mg} \\
\text { ORR: } 63 \% \text { ( } \geq \text { VGPR rate: 95\%) }\end{array}$ & [61] \\
\hline NCT03269136 & 1 & $\mathrm{R} / \mathrm{R} \mathrm{MM}$ & 30 & PF-06863135 & $\begin{array}{l}\text { Fully humanized lgG1- } \\
\text { based bsAb }\end{array}$ & $\begin{array}{l}\text { BCMA/ } \\
\text { CD3 }\end{array}$ & $\begin{array}{l}\text { At the dose of } 215 \text { to } 1000 \mu \mathrm{g} / \\
\mathrm{kg} \mathrm{SC}(\mathrm{n}=20) \text {, } \\
\text { ORR: } 80 \%(6 C R s, 3 \text { VGPRs,6 PRs) }\end{array}$ & [72] \\
\hline NCT03933735 & 1 & $\mathrm{R} / \mathrm{R} \mathrm{MM}$ & 38 & TNB-383B & $\begin{array}{l}\text { Fully humanized lgG1- } \\
\text { based bsAb }\end{array}$ & $\begin{array}{l}\mathrm{BCMA} / \\
\mathrm{CD} 3\end{array}$ & $\begin{array}{l}\text { At the dose of } \geq 40 \text { mg, } \\
\text { ORR: } 80 \% \text { (VGPR rate: } 75 \% \text { ) }\end{array}$ & [64] \\
\hline NCT03275103 & 1 & $\mathrm{R} / \mathrm{R} \mathrm{MM}$ & 51 & Cevostamab & $\begin{array}{l}\text { Fully humanized lgG1- } \\
\text { based bsAb }\end{array}$ & $\begin{array}{l}\mathrm{FcRH} 5 / \\
\mathrm{CD} 3\end{array}$ & $\begin{array}{l}\text { At the dose of } \geq 3.6-20 \mathrm{mg}(n= \\
\text { 29), } \\
\text { ORR: } 51.7 \% \text { ( } 6 \text { CRs, } 4 \text { VGPRs, and } \\
5 \text { PRs) }\end{array}$ & [73] \\
\hline NCT03399799 & 1 & $\mathrm{R} / \mathrm{R} \mathrm{MM}$ & 137 & Talquetamab & $\begin{array}{l}\text { Fully humanized lgG4- } \\
\text { based bsAb }\end{array}$ & $\begin{array}{l}\text { GPRC5D/ } \\
\text { CD3 }\end{array}$ & $\begin{array}{l}\text { At the dose of } 20-180 \mu \mathrm{g} / \mathrm{kg} \text { IV } \\
(\mathrm{n}=18), \\
\text { ORR: } 78 \%(6 / 6 \text { responded at the } \\
60 \mu \mathrm{g} / \mathrm{kg} \text { ) }\end{array}$ & [74] \\
\hline
\end{tabular}


Table 3 Clinical advances with promising published results in other BiTE and T-cell engaging bsAbs (Continued)

\begin{tabular}{|c|c|c|c|c|c|c|c|c|}
\hline $\begin{array}{l}\text { NCT } \\
\text { identifier }\end{array}$ & Phase & Indications & $\begin{array}{l}\text { Number } \\
\text { of } \\
\text { patients }\end{array}$ & Drug & Format & Target & Results & Reference \\
\hline & & & & & & & $\begin{array}{l}\text { At the dose of } 135-405 \mu \mathrm{g} / \mathrm{kg} \\
\text { SC }(n=12) \\
\text { ORR: } 67 \%(3 / 4 \text { responded at the } \\
405 \mu \mathrm{g} / \mathrm{kg})\end{array}$ & \\
\hline NCT02152956 & $1 / 2$ & $\begin{array}{l}\text { PIF and ER } \\
\text { AML }\end{array}$ & 38 & Flotetuzumab & $\begin{array}{l}\text { Two inter-exchange of } \\
\text { Fv domains }\end{array}$ & $\begin{array}{l}\text { CD123/ } \\
\text { CD3 }\end{array}$ & $\begin{array}{l}\text { CRR: } 42.1 \% \text { (7 CR, } 4 \text { CRh, } 4 \text { CRi, } \\
\text { and } 1 \mathrm{MLFS}) \\
\text { In PIF AML }(n=24) \text {, } \\
\text { CRR: } 45.8 \%(5 \mathrm{CR}, 3 \mathrm{CRh} \text {, and } 3 \\
\text { CRi) } \\
\text { In ER AML ( } n=14) \text {, } \\
\text { CRR: } 35.7 \%(2 \mathrm{CR}, 1 \mathrm{CRh}, 1 \mathrm{CRi} \\
\text { and } 1 \mathrm{MLFS})\end{array}$ & {$[75]$} \\
\hline
\end{tabular}

R/R Refractory/relapsed, IG Immunoglobin, bsAb Bispecific antibody, NHL Non- Hodgkin lymphoma, DLBCL Diffuse large B cell lymphoma, FL Follicular lymphoma, MCL Mantle cell lymphoma, ORR Objective response rate, $C R$ Complete remission, CRh Complete remission with partial hematologic recovery, CRi Complete remission with incomplete hematological recovery, PR Partial response, VGPR Very good partial response, CMR Complete metabolic response, CAR Chimeric antigen receptor, CLL Chronic lymphocytic leukemia, aNHL aggressive NHL, iNHL indolent NHL, scFv Single-chain fragment variable, MRD Minimal residual disease, AML Acute Myeloid Leukemia, MM Multiple myeloma, FC Fragment crystallizable, IV Intravenous, SC Subcutaneous, Fv Fragment variable, PIF Primary induction failure, LR Late relapse, MLFS Morphologic leukemia-free state

the negative correlations between disease burden and response rate were also observed in CAR $\mathrm{T}$ cell therapy [95]. Therefore, before the initiation of $\mathrm{T}$-cell engaging therapies such as blinatumomab treatment, administration of cytoreductive therapies such as dexamethasone alone and chemotherapy combined with dexamethasone can be a reasonable strategy for improving response rates for patients with high disease burden [96]. However, it is noted that no standard measurement has been established for disease burden.

Extramedullary disease (EMD) can be regarded as the surrogate for disease burden to an extent, which is one of the known manifestations of advanced hematological malignancies. A retrospective study suggested that a history of the EMD at baseline, as well as the occurrence of EMD during blinatumomab treatment, was associated with lower $\mathrm{CR}$ rates in patients with $\mathrm{R} / \mathrm{R}$ B-ALL $(P=$ 0.005 and $P=0.05$, respectively) [93]. Bone marrow MRD constitutes another surrogate for disease burden. A post hoc analysis evaluated several early parameters for predicting response to blinatumomab in children with R/R B-ALL and identified that day 15 bone marrow MRD could predict complete MRD response to blinatumomab with high accuracy of up to $95 \%$ within the first two treatment cycles [97]. On day 15 of treatment, 59 patients were assessed for MRD, among $46 \mathrm{MRD}$ positive patients, $44 / 46$ patients had no complete MRD response with an accuracy of 96\%, meanwhile, 12/13 patients achieved complete MRD response with an accuracy of $92 \%$ for 13 MRD negative patients [97].

Both BiTE therapy and CAR $\mathrm{T}$ cell therapy are dependent on targeting TAAs on the tumor cell surface, leading to $\mathrm{T}$ cell activation, proliferation, and cytokine production. Thus the density of TAAs should be one of the key factors for effective anti-tumor activity which is associated with treatment efficacy [98]. A previous study suggested that the CD20 density was no less than 200 molecules per target cell for inducing CAR $T$ cellmediated cytolysis while $\sim 10$-fold higher antigen density was required for cytokine production for an anti-CD20 CAR T cell construct in vitro experiments [99]. A quantitative systems pharmacology (QSP) model was developed to assess some other factors affecting blinatumomab antitumor efficacy in NHL patients, besides tumor antigen density, factors significant for anti-tumor efficacy were blinatumomab density, rate of redirected $\mathrm{T}$ cell lysis, tumor cell growth rate, and E/T ratio [100, 101]. Potential biomarkers for predicting response included tumorinfiltrating lymphocytes (TILs), primarily $\mathrm{T}$ cells, and tumor growth rate [101]. However, it should be noted that the number of regulatory $\mathrm{T}$ cells (Tregs) was inversely correlated with the response rate to blinatumomab in patients with R/R B-ALL [102]. Blinatumomab responders $(n=22)$ had an average Tregs of $4.82 \%$ (CI: $1.79-8.34 \%)$ in the peripheral blood, whereas it was $10.25 \%$ (CI: $3.36-$ $65.9 \%)$ for non-responders $(n=20)$. All of the blinatumomab responders were successfully identified by the Treg cutoff of $8.525 \%$, while $70 \%$ of the non-responders were excluded by this threshold.

The analysis of the relationship between tumor genetic features and treatment response is a useful way to select potential biomarkers for predicting outcomes of patients and guiding treatment decisions in the clinic. A recent study characterized the genetic profile in 44 adults with R/R B-ALL treated with blinatumomab to find out potential biomarkers to blinatumomab therapy [94]. Sixteen Ph-like patients with CRLF2 rearrangement had a higher response rate of $75 \%$, whereas the response rate was $55 \%$ in the overall cohort. More importantly, the partial deletion of exon 2 of CD19, CD19 ex2part, was 
Table 4 Ongoing clinical trials of BiTE and other CD3-targeting T-cell engager bsAbs in solid tumors

\begin{tabular}{|c|c|c|c|c|c|c|c|}
\hline NCT & Phase & Indications & $\begin{array}{l}\text { Number of } \\
\text { patients }\end{array}$ & Drug & Target & Results & Reference \\
\hline NCT01723475 & 1 & $\begin{array}{l}\text { Metastatic castration-resistant pros- } \\
\text { tate cancer }\end{array}$ & 47 & Pasotuxizumab & $\begin{array}{l}\text { CD3/ } \\
\text { PSMA }\end{array}$ & $\begin{array}{l}\text { In SC group }(n=31) \\
>50 \% \text { PSA decline rate:21\% } \\
\text { In cIV group }(n=16) \\
>50 \% \text { PSA decline rate: } 19 \%\end{array}$ & {$[77]$} \\
\hline NCT03792841 & 1 & $\begin{array}{l}\text { Metastatic castration-resistant pros- } \\
\text { tate cancer }\end{array}$ & 43 & AMG 160 & $\begin{array}{l}\text { CD3/ } \\
\text { PSMA }\end{array}$ & $\begin{array}{l}\text { Any PSA decline rate: } 68.6 \% \\
>50 \% \text { PSA decline rate: } 34.3 \% \\
\text { In patients with evaluable } \\
\text { disease ( } n=15 \text { ), } \\
\text { there are } 3 \text { PRs and } 8 \text { SD }\end{array}$ & [78] \\
\hline NCT03296696 & 1 & R/R Glioblastoma & 15 & AMG 596 & $\begin{array}{l}\text { CD3/ } \\
\text { EGFRvIII }\end{array}$ & $\begin{array}{l}\text { In patients with sufficient } \\
\text { follow-up }(n=8) \text {, } \\
\text { there are } 1 \text { PR and } 2 \text { SD }\end{array}$ & {$[80]$} \\
\hline NCT03319940 & 1 & R/R Small-cell lung cancer & 40 & AMG 757 & $\begin{array}{l}\text { CD3/ } \\
\text { DLL3 }\end{array}$ & $\begin{array}{l}\text { In patients with evaluable } \\
\text { disease }(n=38) \text {, } \\
\text { there are } 6 \text { confirmed PRs, } 11 \\
\text { SD, and } 1 \text { unconfirmed PR }\end{array}$ & [81] \\
\hline NCT04117958 & 1 & Gastric cancer & - & AMG 199 & $\begin{array}{l}\text { CD3/ } \\
\text { MUC } 17\end{array}$ & Not reported & [82] \\
\hline NCT04260191 & 1 & Gastric cancer & - & AMG 910 & $\begin{array}{l}\text { CD3/ } \\
\text { CLDN18.2 }\end{array}$ & Not reported & [83] \\
\hline NCT04128423 & 1 & R/R solid tumors & 11 & AMV564 & $\begin{array}{l}\text { CD3/ } \\
\text { CD33 }\end{array}$ & $\begin{array}{l}\text { In patients with evaluable } \\
\text { disease }(n=9) \text {, } \\
\text { there are } 1 \text { PR and } 4 \text { SD }\end{array}$ & [84] \\
\hline NCT02324257 & 1 & CEA+ advanced solid tumors & 80 & Cibisatamab & CD3/CEA & $\begin{array}{l}\text { In patients with } \mathrm{mCRC} \text { at doses } \\
\geq 60 \mathrm{mg}(n=36) \\
\text { Metabolic PR rate: } 28 \%\end{array}$ & [85] \\
\hline NCT04501770 & 1 & HER2+ advanced solid tumors & - & M802 & $\begin{array}{l}\text { CD3/ } \\
\text { HER2 }\end{array}$ & Not reported & {$[86]$} \\
\hline NCT04501744 & 1 & Malignant ascites & - & M701 & $\begin{array}{l}\text { CD3/ } \\
\text { EpCAM }\end{array}$ & Not reported & [87] \\
\hline NCT02748837 & 1 & Solid malignancies & - & ERY974 & $\begin{array}{l}\mathrm{CD} 3 / \\
\mathrm{GPC} 3\end{array}$ & Not reported & [88] \\
\hline NCT02248805 & 1 & R/R Metastatic colorectal carcinoma & 95 & MGD007 & $\begin{array}{l}\text { CD3/ } \\
\text { gpA33 }\end{array}$ & Not reported & [89] \\
\hline NCT02262910 & 1 & $\begin{array}{l}\text { Metastatic castration-resistant pros- } \\
\text { tate cancer }\end{array}$ & 35 & ES414 & $\begin{array}{l}\text { CD3/ } \\
\text { PSMA }\end{array}$ & Not reported & [90] \\
\hline NCT03860207 & 1 & $\begin{array}{l}\text { R/R Neuroblastoma, osteosarcoma, } \\
\text { and other GD2+ solid tumors }\end{array}$ & - & Hu3F8-bsAb & $\mathrm{CD} 3 / \mathrm{GD} 2$ & Not reported & [91] \\
\hline NCT03983395 & $1 / 2$ & HER2+ metastatic breast cancers & - & ISB 1302 & $\begin{array}{l}\text { CD3/ } \\
\text { HER2 }\end{array}$ & Not reported & - \\
\hline NCT03448042 & 1 & $\begin{array}{l}\text { Locally advanced or metastatic } \\
\text { HER2+ cancers }\end{array}$ & - & BTRC4017A & $\begin{array}{l}\text { CD3/ } \\
\text { HER2 }\end{array}$ & Not reported & - \\
\hline NCT04424641 & - & $\begin{array}{l}\text { Locally advanced or metastatic solid } \\
\text { tumors }\end{array}$ & - & GEN1044 & $\mathrm{CD} 3 / 5 \mathrm{~T} 4$ & Not reported & - \\
\hline
\end{tabular}

$R / R$ Refractory/relapsed, PSMA Prostate-specific membrane antigen, $C I V$ Continuous intravenous, SC Subcutaneous, PSA Prostate-specific antigen, CR Complete remission, PR Partial response, SD Stable disease, EGFRvIII The epidermal growth factor receptor variant III, DLL3 Delta-like 3, MUC 17 Mucin 17, CLDN18.2 Claudin18 splice variant 2, CEA Carcinoembryonic antigen, Her2 Human epidermal growth factor receptor 2, EpCAM Epithelial cellular adhesion molecule, GPC3 Glypican 3, gpA33 Glycoprotein A33, GD2 Disialoganglioside

identified as a potential biomarker that predicted response to blinatumomab. In contrast to the responders, CD19 ex2part levels were significantly higher in blinatumomab-unresponsive patients by analyzing samples from pre-treatment patients $(P=0.025)$. Additionally, samples from post-treatment patients with relapse presented higher CD19 ex2part levels compared with those from pre-treatment patients, which indicated that CD19 ex2part accumulated during treatment and likely led to treatment failure $(P=0.0002)$ [94]. The predictive role of CD19 ex2part as a biomarker should be confirmed by future research for CD19-targeted immunotherapies, as well as exploring other potential biomarkers relative to TAAs. 


\section{Toxicity}

The safety profile of BiTE immunotherapy is of considerable concern to physicians and patients. As the only marketed member of BiTE family, the safety profile of blinatumomab is fully elucidated. In the phase 3 TOWER study, grade $\geq 3$ AEs were ordered according to the frequency of occurrences, the top five were neutropenia, infection, elevated liver enzyme, neurotoxicity, and CRS [40]. Among them, the most concerning AEs are CRS and neurotoxicity which have proven doselimiting toxicities (DLTs) and can even lead to death $[103,104]$. CRS is an uncontrolled systemic inflammatory response with elevated levels of pro-inflammatory cytokines, primarily IL-6, which is triggered by $\mathrm{T}$ cell activation in $\mathrm{T}$ cell-engaging immunotherapies such as BiTE therapy and CAR T cell therapy [105]. CRS-related symptoms can range from mild flu-like symptomatology to severe and fatal multi-organ failure [105]. CRS often occurs in the first several days after BiTE infusion and the risk of grade $\geq 3$ CRS in pivotal studies ranges from 0 to $6 \%$ for B-cell malignancies, in addition, a higher incidence of CRS is associated with higher tumor burden and drug doses [35, 38-40,43, 46, 47]. The strategy of prophylactic use of dexamethasone combined with stepwise administration of blinatumomab is useful to decrease the risk of CRS [38]. After initiation of blinatumomab, interleukin (IL)-6 receptor inhibitor tocilizumab and corticosteroid are effective to treat severe CRS, while mild CRS can be addressed by symptomatic treatment [105].

Neurotoxicity is another unique treatment-related AEs for patients treated with $\mathrm{T}$-cell engaging therapies, which is also termed as immune effector cell-associated neurotoxicity syndrome (ICANS). The incidence of grade $\geq 3$ neurotoxicity ranges from 5.5 to $24 \%$ in these clinical studies related to blinatumomab [32, 35, 38-44, 47]. Neurotoxicity occurs mainly in treatment cycle 1 and the risk of neurotoxicity is increased when given higher doses of blinatumomab with the most common symptoms of dizziness, tremor, confusional state, and encephalopathy [104]. However, pathogenic mechanisms responsible for neurotoxicity induced by $\mathrm{T}$ cell-based anti-cancer therapies are complex and incompletely understood [106]. There was preclinical and clinical evidence that the adhesion of $\mathrm{T}$ cells to endothelial cells contributed to neurotoxicity induced by blinatumomab based on analyses of selected patients from 5 clinical trials and data from in vitro experiments [107]. Blinatumomab induced peripheral $\mathrm{T}$-cell recruitment to the brain involving the following process: $\mathrm{T}$ cells adhered to cerebral microvascular endothelium, endothelial cells were activated with an increased level of Ang-2 (a marker of endothelial cell activation), $\mathrm{T}$ cells transmigrated across the blood-brain barrier into the brain. And then these $\mathrm{T}$ cells eliminated resident B cells with the release of cytokines, leading to an excessive immune response and ultimately resulting in neurotoxicity. The study suggested that agents inhibiting the adhesion between $\mathrm{T}$ cells and blood vessel endothelium could be an effective modality to reduce the incidence of neurotoxicity [107]. Interventions used routinely to treat neurotoxicity are interrupting treatment and dexamethasone [104].

To reduce minimize the risk of key systemic toxicity such as CRS, the safety, PK profile, and efficacy with subcutaneous (SC) administration of blinatumomab, a novel route of administration, is being evaluated in $R / R$ B-ALL (NCT04521231) and R/R NHL (NCT02961881). In comparison to IV infusion, other potential benefits of SC injection include improved convenience and compliance and a reduction of cost for patients receiving treatment. Preliminary results regarding other bAbs that redirect $\mathrm{T}$ cells have been reported, suggesting $\mathrm{SC}$ injection did reduce the maximum concentration associated with CRS with high bioavailability, SC dosing is therefore a preferable route of administration for mitigating CRS and increasing the dose intensity $[108,109]$.

\section{Resistance to BiTE therapy}

Despite the success of BiTE therapy with blinatumomab against B-cell malignancies expressing CD19, a significant portion of patients does not respond to treatment or they eventually relapse even with initial responses. The resistance to blinatumomab appears to involve multiple mechanisms, at present, studies have mainly focused on two aspects including immunosuppressive factors and loss of CD19 antigen (Fig. 2). Numerous studies have elucidated the key role of immune checkpoints in the suppression of anti-tumor immune responses, antibodies blocking the PD-1/PD-L1 axis have led to remarkable clinical efficacy for various malignancies [110]. Five years ago a case report described a patient with $\mathrm{R} / \mathrm{R}$ B-ALL who experienced an increase in PD-1 and PD-L1 positivity after treatment with blinatumomab, in vitro experiments showed the ability of $\mathrm{T}$ cells inducing tumor cell lysis was weakened with a lower level of interferon $\gamma$ (IFN- $\gamma$ ) in this patient [111]. Subsequent studies confirmed the finding that the expression of inhibitory immune checkpoints, mainly PDL1, was increased after BiTE treatment in ex vivo cytotoxicity experiments and patients with different hematologic neoplasms, suggesting the addition of checkpoint inhibitors to BiTE therapy was a feasible strategy to improve BiTE-mediated cytotoxicity [100, 112]. Various solid tumor cells express immune checkpoint proteins on their surface that bind to inhibitory receptors on $\mathrm{T}$ cells, dampening the $\mathrm{T}$-cell immune response and compromising the efficacy of $\mathrm{T}$ cell-based immunotherapies such as CAR T cell therapy and BiTE 


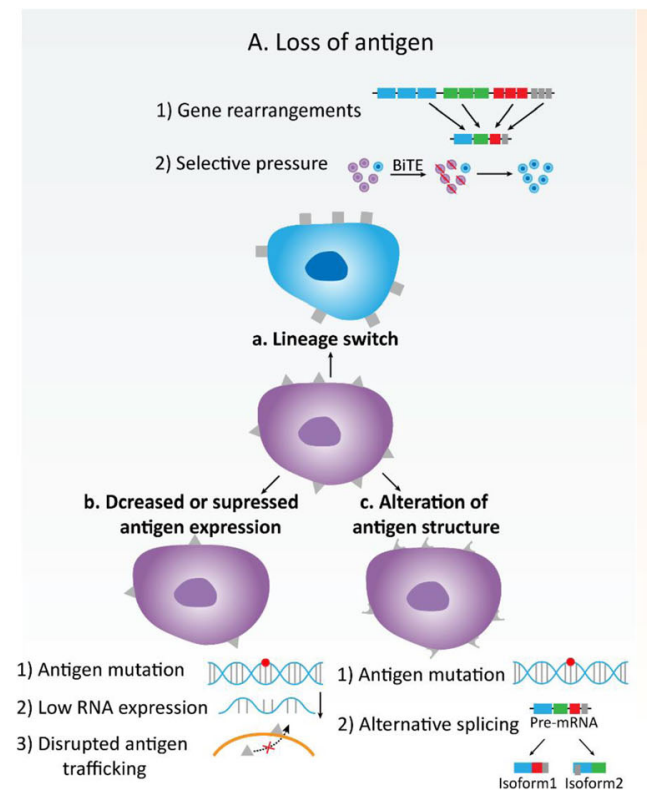

B. Immunosupressive TME

a. Immunosupressive receptors (eg. PD-1/PD-1)

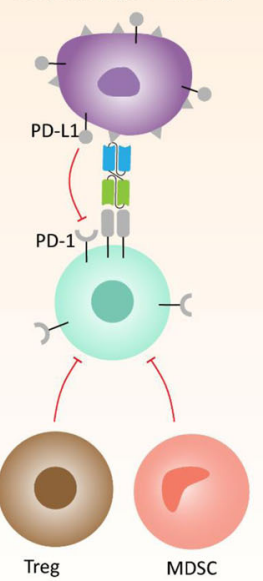

b. Immunosupressive cells (eg. Treg, MDSC)

Fig. 2 Summary of currently identified mechanisms of tumor evasion to BiTE therapy. A. Loss of antigen---possible mechanisms: a. Lineage switch associated with 1) Gene rearrangement 2) Selective pressure due to bispecific T cell engager (BiTE) therapy b. Decreased or suppressed antigen expression associated with 1) Antigen mutation 2) Low RNA levels 3) Disrupted antigen trafficking process c. Alteration of antigen structure associated with 1) Antigen mutation 2) Alternative spicing B. Immunosuppressive tumor microenvironment (TME)---possible mechanisms: a. Immunosuppressive receptors such as PD-1/PD-L1 axis b. Immunosuppressive immune cells such as T regular (Treg) cells and MDSCs: Myeloid-derived suppressor cells; PD1: Programmed cell death 1; PD- L1: Programmed cell death 1 ligand 1

therapy [113]. Thus with the inhibition of immune checkpoints, the indications of BiTE therapy as well as CAR $\mathrm{T}$ cell therapy will expand including for both hematologic malignancies and solid tumors. The immunosuppressive cells in tumor microenvironment (TME) also present critical obstacles for effective immunotherapies, the most prominent representative is glioblastoma which is known to contain a dominance of immunosuppressive myeloid cells [114]. Tumors utilize Treg to suppress the tumor-specific immune response and promote their development, inhibition of blinatumomab efficacy by increasing levels of Treg measured by $\mathrm{CD} 4 / \mathrm{CD} 25 / \mathrm{FOXP} 3$ expression has been identified during blinatumomab treatment in patients with R/R BALL [102, 115]. Myeloid-derived suppressor cells (MDSCs), as another important component of immunosuppressive cells in TME, have received increasing attention in recent years that contribute to tumor development growth and progression [116]. A recent study identified neutrophils with the expression of CD11b/CD13/CD16 belonged to granulocytic MDSCs (G-MDSCs) in patients with MM, moreover, depleting these immunosuppressive cells could improve the cytotoxic activity of BCMA/CD3 bsABs [117]. Collectively, with the deep understanding of immunosuppressive factors in TME further related targeted therapies will combat resistance to current $\mathrm{T}$-cell based immunotherapies.
Although B-ALL patients with initial CD19 positivity achieved CR after blinatumomab treatment, a considerable proportion of patients experienced relapse and CD19-negative relapse contributed to $8-50 \%$ of overall relapse [32, 33, 38, 42, 93, 118]. The targeted antigen loss was also observed in patients who were refractory to anti-CD19 CAR $\mathrm{T}$ cell treatment, suggesting the critical role of antigen loss in resistance to $\mathrm{T}$-cell based cancer immunotherapies $[119,120]$. Antigen loss can be interpreted as the loss of antigen expression and the loss of antigen-binding to targeted antibodies or cells, the presence of either situation or both can lead to the CD19-negative relapse. A study analyzed data from four B-ALL patients who had been treated with blinatumomab and experienced CD19-negative relapse and found that CD19 trafficking from the intracellular space to the membrane of B cells was prevented with the lack of CD81 that provided docking sites for CD19 signal transduction, resulting in absent CD19 expression [121]. CD19 mutations including frame-shift insertion or deletions, inframe deletion, non-sense mutations, and splice-site single nucleotide variants (SNVs) were observed in five of seven R/R B-ALL patients who had CD19negative relapse after blinatumomab treatment, suggesting CD19 mutations were common. Moreover, mechanisms of CD19 mutant allele-specific 
expression, low CD19 RNA expression, and mutations in CD81 which were in line with the previous study were also identified as partial causes of loss of CD19 expression [94]. Besides decreased or suppressed CD19 expression, notably, it was observed that usage of CD19 RNA isoform ex2part was increasing due to alternative splicing in both CD19-positive and CD19negative relapses, which caused antigen escape by changing CD19 epitopes and ultimately disrupting the binding of blinatumomab to CD19 molecule rather than reducing CD19 expression [94]. One patient with CD19-negative relapse presented both antigen mutations and increased alternatively spliced RNA isoforms, suggesting they are likely to occur in parallel and responsible for antigen loss [94]. Alternative splicing and CD19 mutations were also demonstrated in other CD19-targeted immunotherapies such as CAR $\mathrm{T}$ cell therapy [122, 123]. Interestingly, the lineage switch of B lymphocytes from the lymphoid lineage to the myeloid lineage can be seen in patients with B-ALL who experienced CD19-directed immunotherapy in which CD19 expression was lost while myeloid marker levels such as CD33 were upregulated [124, 125]. The reasons for lineage switch may be associated with a strong selective advantage for subclones who did not express CD19 and gene rearrangements such as KMT2A/AFF1 and ZNF384 [126-128]. Therefore, multitargeted strategies may be effective to overcome antigen loss including developing a single drug that can simultaneously target dual or multiple TAAs or combining various immunotherapies that each of these targets a different TAA [129, 130].

\section{Development of novel T-cell engager antibodies}

Despite the clinical success of blinatumomab against Bcell malignancies, many obstacles remain such as inconvenient routes of administration, treatment resistance, and limited efficacy in solid tumors. To overcome these limitations, considerable efforts have been dedicated to structural modifying canonical BiTE construct and developing multifunctional $\mathrm{T}$-cell engaging antibodies, while some of them have entered the clinical stage (Fig. 3).

\section{HLE-BiTE}

Canonical BiTE antibody is composed of only two scFvs without the Fc domain that possesses the ability to extend circulation time, thus this small molecule can be quickly cleared through the kidney with a short half-life, which requires continuous intravenous infusion to maintain therapeutic serum concentrations [131]. To overcome this limitation and also to further reduce treatment cost, HLE-BiTE has been designed by adding an Fc domain to a BiTE molecule and patients require only a single administration per week [132]. However, there is concern that prolonged serum drug concentration may be associated with increased toxicity compared with canonical BiTE that quickly gets cleared by stopping the infusion. Clinical trials for a variety of HLEBiTE antibodies are currently underway in both hematological malignancies and solid tumors, they have been summarized by the previous review [30]. For example, there are published preliminary data from a phase 1 first-in-human study for HLE-BiTE AMG 673, which targets $\mathrm{CD} 33$ in patients with $\mathrm{R} / \mathrm{R}$ AML

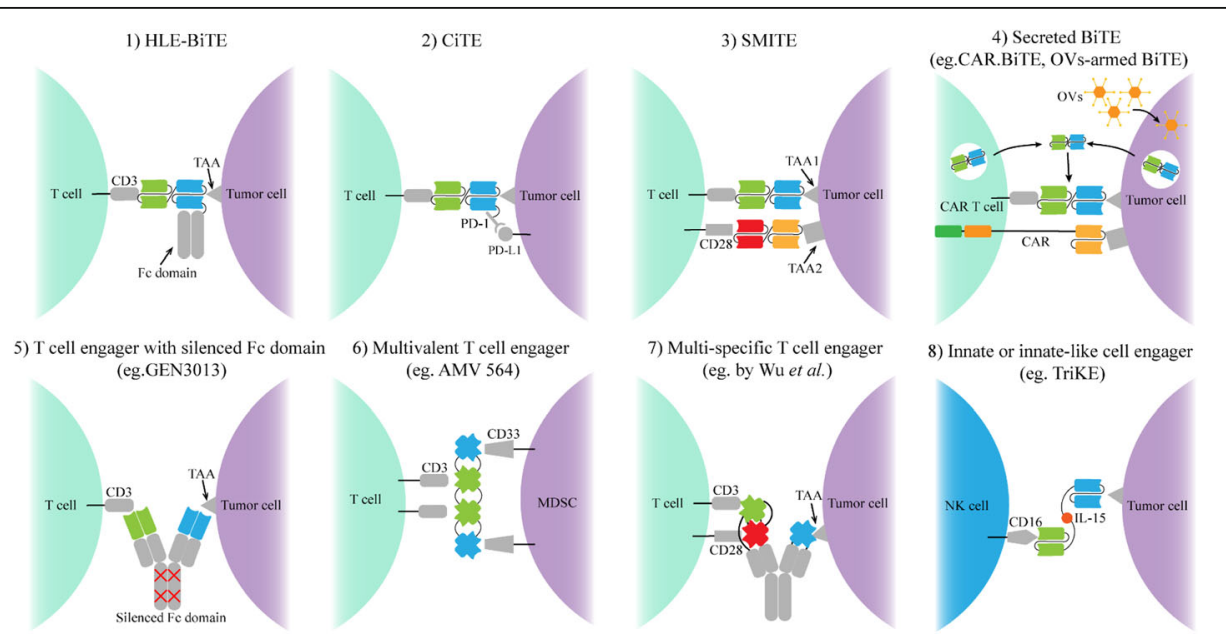

Fig. 3 Schematic overview of the development of novel immune cell-based engager antibodies 1) Half-life extended-bispecific T cell engager (HLE-BiTE) 2) Checkpoint inhibitory T cell-engaging (CiTE) 3) Simultaneous multiple interaction T-cell engaging (SMiTE) 4) Secreted BiTE (eg. CAR.BiTE, OVs-armed BiTE) 5) T cell engager with silenced Fc domain 6) Multivalent T cell engager 7) Multi-specific T cell engager 8) Innate or innate-like cell engager CAR: chimeric antigen receptor OVs: Oncolytic viruses 
(NCT03224819) [53]. Thirty patients were enrolled and $67 \%$ of them had been treated with more than 4 antiAML treatments. The mode of administration was a short IV infusion once a week in a two-week cycle, and patients were equally distributed in 10 cohorts with doses ranging from $0.05-72 \mu \mathrm{g}$. The median treatment cycle was 1.5 . The incidence of treatment-related grade $\geq$ 3 AEs was $50 \%(15 / 30)$ including 5 abnormal hepatic enzyme, 4 CRS, 4 leukopenia, 2 thrombocytopenia, and 2 febrile neutropenia. The incidence of grade 3 CRS was $13.3 \%$. Of the 27 evaluable patients, 11 (41\%) presented a decrease in bone marrow blasts with one patient achieving a CRi at the dose of $36 \mu \mathrm{g}$ [53]. Updated results showed 2 DLTs were observed in the additional dose cohort $(110 \mu \mathrm{g})$, thus $110 \mu \mathrm{g}$ was identified as MTD for further dose escalation [133]. Subsequent results from ongoing clinical trials for AMG 673 as well as other HLE-BiTE antibodies are expected.

\section{CiTE and SMiTE}

It is established that the upregulation of immune checkpoints, such as PD-1/PD-L1, is one of the acquired resistance mechanisms to BiTE therapy [111]. The previous study found a significantly increased expression of PD-L1 when AMG 330 was added to AML cells in vitro, whereas immune blockade of the PD-1/PD-L1 interaction can greatly enhance the AMG 330-mediated cytotoxicity [100]. Thus, a novel bifunctional checkpoint inhibitory T cell-engaging (CiTE) antibody has been developed by fusing the PD-1 extracellular domain with low affinity to the canonical anti-CD33 BiTE construct [134]. Decreasing the affinity of the PD-1 extracellular domain to PD-L1 aims to restrict the development of immune-related AEs due to on-target off-leukemia toxicity, meanwhile, the affinity to CD33 tumor antigen is still high, which aims to maintain high specificity for CD33 + PD-L1+ double-positive cells other than all PDL1+ cells. In vitro experiments, the CiTE antibody indeed showed a potent ability to activate $\mathrm{T}$ cells with an increased level of IFN $-\gamma$ and cause cytotoxic lysis with high specificity for both CD33 + PD-L1 + cells and patient-derived AML cells [134]. CiTE can be a promising modified BiTE construct and is needed to be evaluated in more humanized models.

In general, activation of naive $\mathrm{T}$ cells requires at least two signals including TCR signal and costimulatory signal [135]. BiTE can generate TCR signal by binding to both CD3 and TAAs and form a powerful immunologic synapse between cytotoxic $\mathrm{T}$ cells and tumor cells, independent of the costimulatory signal [23]. However, a locally improved cytotoxic effect was observed in vitro and vivo studies when adding CD137, a potent costimulatory immunoreceptor, to BsAbs [136, 137]. Moreover, studies reported that activation of another costimulatory molecule CD28 enhanced the cytotoxicity of the BiTE antibody AMG 330 in primary human AML cells [138]. Thus, simultaneous multiple interaction T-cell engaging (SMITE) consisting of two separated canonical BiTE antibodies has been developed, both of the antibodies target TAAs on the one side while binding to either CD3 or CD28 on the other, providing additional costimulatory activation to enhance anti-tumor activity than either BiTE antibody alone [139]. In addition to targeting two different TAAs, one of BiTE antibodies can also target inhibitory immune checkpoints to overcome adaptive immune escape of tumor cells, mainly PD-L1, thus the SMITE pair was composed of CD3/TAA BiTE and CD28/PD-L1 BiTE [139].

\section{Secreted BiTE}

The current delivery route for BiTE and other T cell engaging antibodies is through intravenous administration passively, while standard human antibodies are actively secreted by plasma cells under normal physiological conditions. If these therapeutic antibodies with a potent anti-tumor function are also secreted by living cells in the human body, it may maintain a stable therapeutic concentration and exert durable anti-tumor effects without continuous infusion, furtherly, BiTE-secreting cells should specifically target the tumor regions or these secreted cells themselves are even tumor cells to provide local production of BiTE antibody without increased systemic toxicity. Currently, CAR T cells and oncolytic viruses (OVs) are selected to express BiTE antibody by gene modification, which integrates two complimentary cancer immunotherapies into one vehicle that is expected to synergistically improve anti-tumor activity, especially in solid tumors for which the efficacy of either therapy alone is insufficient [140, 141]. In patients with GBM, although CAR-T cells targeting EGFRvIII decreased the number of EGFRvIII-expressing tumor cells, subsequent analysis of surgical samples showed a high level of wild-type EGFR in the tumor site. Therefore, Choi et al. proposed the concept of CART.BiTE and developed a kind of CART.BiTE product that was the special CAR-T cells targeting EGFRvIII that secreted EGFRtargeted BiTE antibodies. These CART.BiTE cells had effective anti-tumor activity against GBM with heterogeneous and even negative EGFRvIII expression in mouse models, precluding immune escape due to antigen loss with no toxicity observed in mice transplanted with human skin [140].

In recent years, BiTE and OVs have been merged into a single platform by arming OVs with a therapeutic transgene encoding BiTE, which is termed as BiTEarmed OVs. These modified viruses preferentially infect and replicate in tumor cells, ultimately inducing oncolysis, meanwhile, tumor cells infected with BiTE-armed 
OVs can trigger T-cell activation and lead to bystander killing of non-infected tumor cells, which greatly enhances anti-tumor activity than unmodified OVs [141]. By the use of OVs as BiTE gene delivery vehicles, BiTE can be secreted locally at the tumor site due to the tumor specificity of OVs, which minimizes BiTEmediated systemic toxicity. In addition to targeting tumor cells, BiTE-armed OVs can be also used to target cells that promote tumor progression in TME such as immunosuppressive stromal cells and M2-like tumorassociated macrophages (TAMs) [142, 143]. Moreover, in addition to a gene encoding BiTE antibodies, OVs can be also equipped with expression cassettes encoding cytokine, checkpoint inhibitors, and other molecules that have effective anti-tumor activity. Recently, OVs that were capable of producing BiTE antibodies targeting TAA of CD44 variant 6 (CD44v6), interleukin-12 (IL-12, an immunostimulatory cytokine), and anti-PD-L1 antibodies were developed, while these multifunctional OVs in combination with CAR $\mathrm{T}$ cells targeting TAA of HER2 enabled a substantial improvement of disease control in CD44v6 positive tumors with heterogeneity HER2 expression, overcoming multiple resistance mechanisms of tumor antigen loss and inhibitory effect of immune checkpoints which are major obstacles for single immunotherapy in the treatment of solid tumors [144]. Consequently, integrating BiTE therapy with other bioactive cancer immunotherapies possessing tumortargeting ability including CAR $\mathrm{T}$ cell and OVs therapy into one platform that enables actively secret BiTE antibodies is a promising research direction, retaining their respective advantages and compensating for their limitations to maximize therapeutic benefits while reducing BiTE-induced systemic toxicity.

\section{T cell engager with silenced $\mathrm{Fc}$ domain}

The interaction between the Fc domain and its receptor on multiple immune cells can induce nonspecific immune activation such as ADCC, which leads to unwanted toxicity, however, the existence of the Fc domain enables antibodies to prolong the half-time. Thus, many antibodies with silent Fc domains have been developed by introducing point mutations that abrogate the binding of Fc receptors to Fc domains to reduce or avoid unnecessary effector functions while retaining the ability to extend the half-time [88, 145-151]. For example, GEN3013, a full-length human IgG1 bsAb recognizing CD3 and CD20, was generated by controlled Fab-arm exchange. Its Fc domain was silenced by the introduction of mutations L234F L235E D265A [151]. A phase $1 / 2$ clinical trial is ongoing to evaluate the safety and efficacy of GEN3013 in patients with R/R B-cell lymphoma (NCT03625037). Moreover, recent studies have suggested that bsAbs with silenced Fc domains were able to improve the infiltration of $\mathrm{T}$ cells into solid tumors and enhance anti-tumor effects in the tumor xenograft mice, whereas bsAbs with intact Fc domains failed to induce $\mathrm{T}$-cell trafficking to the tumor site because Fc-mediated effector functions enabled $\mathrm{T}$ cells to be sequestered in the reticuloendothelial system or depleted in circulation [152].

\section{Multivalent and multi-specific $\mathrm{T}$ cell engager}

BiTE is a bispecific and bivalent antibody, therefore, it should be possible to enhance the anti-tumor activity and mitigating antigen loss by using multivalent and/or multi-specific $\mathrm{T}$ cell engager antibodies that carry multiple antigen-binding sites to increase binding affinity and/or recognize more different TAAs and molecules involving T-cell activation. Numerous multivalent $\mathrm{T}$ cell engager molecules are under active development and some of them have yielded promising results in early clinical trials $[56,62]$. For instance, AMV 564, a tetravalent bispecific molecule, has 2 binding sites for CD3 on $\mathrm{T}$ cells and 2 binding sites for CD33 on MDSCs with 2:2 antigen-binding valency. MDSCs play an important role in mediating immune suppression and promoting tumor growth, which can serve as a novel target for many malignant diseases, thus, AMV 564 can eliminate immunosuppressive MDSCs and drive $\mathrm{T}$ cell activation and proliferation to effectively induce anti-tumor immunity [153]. In phase 1 first-in-human trial (NCT03144245), AMV564 was well-tolerated and effective in patients with R/R AML [56]. Moreover, interim results of an ongoing phase 1 study (NCT04128423) have shown that AMV 564 had anti-tumor activity in multiple solid tumors with tolerable toxicity [84]. Besides increasing antibody valency, developing multi-specific $\mathrm{T}$-cell engager antibodies that direct at multiple molecules associated with anti-tumor immunity is intended to provide greater efficacy and overcome treatment resistance with lower toxicity. A trispecific T-cell engager antibody has been developed that simultaneously binds to CD3, CD28, and CD38, both CD3 and CD28 engagement resulted in superior $\mathrm{T}$ cell activation, while the recognition of CD38 redirects $\mathrm{T}$ cells against $\mathrm{MM}$ and other hematologic malignancies with powerful killing efficiency [154]. Although clinical trials regarding this trispecific antibody have not been performed in humans, the integration of multiple specificities into one protein is a promising next-generation $\mathrm{T}$ cell engager immunotherapy and deserves further investigation.

\section{Combination strategies Chemotherapy}

Hyperfractionated cyclophosphamide, vincristine, doxorubicin, and dexamethasone (Hyper-CVAD) is a commonly used chemotherapy regimen for patients with newly diagnosed B-ALL, which can be served as a 
backbone for the development of new regimens [155]. A phase 2 study is evaluating the regimen of Hyper-CVAD in sequential combination with blinatumomab in adults with newly diagnosed B-ALL [156]. The regimen included 4 cycles of Hyper-CVAD followed by 4 cycles of blinatumomab. Twenty-seven patients were included, the median Hyper-CVAD treatment cycles were 3 while the median blinatumomab treatment cycles were 2 , the rate of patients who underwent HSCT for high-risk features was $30 \%$. The overall CR rate was $100 \%$ with an MRD-negativity response rate of $96 \%$. With a median follow-up of 17 months, the 12-month RFS and OS rates were 76 and $89 \%$, respectively. The incidence of blinatumomab-related grade $\geq 3$ neurotoxicity was $17 \%$ while it was $4 \%$ for grade $\geq 3$ CRS [156]. Two additional studies have also demonstrated the role of blinatumomab in combination with chemotherapy as front-line therapy in adults with newly diagnosed Ph- B-ALL with tolerable toxicity $[157,158]$. In addition, blinatumomab monotherapy after current standard-of-care chemotherapy: a regimen of rituximab combined with cyclophosphamide, doxorubicin, vincristine, and prednisolone ( $\mathrm{R}$ CHOP) have achieved an ORR of $89 \%$ in patients with newly diagnosed high-risk DLBCL [159].

To further improve treatment outcome in patients with $R / R$ disease, triple therapy based on the sequential addition of blinatumomab to the combination of lowintensity chemotherapy (mini-hyper-CVD) and inotuzumab ozogamicin, an anti-CD22 antibody-drug conjugate (ADC), has presented superior clinical benefits as the first salvage therapy compared to conventional intensive chemotherapy and single-agent inotuzumab ozogamicin in patients with R/R ALL with reducing the dose of inotuzumab ozogamicin and minimizing the risk of liver veno-occlusive disease (VOD) [160]. With a median follow-up of 3 years, the ORR was $80 \%$ with an MRD response rate of $83 \%$, three-year CR duration and OS rates were 32 and 33\%, respectively [161]. Numerous clinical studies evaluating the safety and efficacy of blinatumomab in combination with chemotherapy in the treatment of patients with newly diagnosed or R/R B-ALL are ongoing (Table 5).

\section{Targeted therapy}

Tyrosine kinase inhibitors (TKIs) targeting BCR-ABL1 are effective in the treatment of patients with $\mathrm{Ph}+$ leukemia, however, acquired resistance to TKI therapy remains a clinical challenge with limited therapeutic options. The retrospective study reported the encouraging efficacy of the combination strategy of blinatumomab and TKIs in patients with $\mathrm{R} / \mathrm{R} \mathrm{Ph}+\mathrm{B}$-ALL [162]. Among 16 patients with $R / R$ disease, the $C R$ rate was $88 \%$ with an MRDnegativity response rate of $86 \%$. With a median follow-up of 15 months, the 12 -month survival rate was $80 \%$ and the median OS following blinatumomab therapy was 45 months. Several other retrospective studies have also shown that blinatumomab combined with TKIs was safe and effective in patients with $\mathrm{R} / \mathrm{R} \mathrm{Ph}+$ disease $[163,164]$. However, these studies are limited by retrospective design and small sample sizes, a prospective trial is investigating the efficacy of dasatinib, a second-generation TKI, in combination with blinatumomab as a front-line treatment in adults with Ph + ALL [165]. The regimen mainly consists of induction-phrase with dasatinib for 85 days and consolidation-phrase with blinatumomab. Among 63 patients treated with this regimen, the CR rate was $98 \%$, the molecular response rate was $29.3 \%$ after completion of dasatinib-induction treatment and increased as the number of blinatumomab cycles increased $(56.3 \%$ after 2 cycles of blinatumomab treatment, $65.7 \%$ after three cycles and $80 \%$ after 4 cycles). With a median follow-up of 10 months, the 12-month OS and disease-free survival (DFS) were 94.2 and $87.8 \%$, respectively. Moreover, a recent case report has shown the combination of venetoclax, a selective inhibitor of the B-cell lymphoma 2 (Bcl-2), and blinatumomab is a highly effective and safe treatment against MRD relapse in patients with B-ALL [166]. Two patients achieved MRD-negativity responses soon after the complete blinatumomab treatment followed by venetoclax and underwent HSCT with no AEs. Several prospective trials to provide reliable evidence for this combination are ongoing (NCT02744768, NCT02997761, NCT04530565).

\section{Immune checkpoint inhibitors}

The upregulation of immune checkpoints is one of the major mechanisms involved in resistance to BiTE therapy. The combination therapy with ICIs can reactivate an exhausted immune response and improve anti-tumor activity, thus several related clinical studies have been conducted. A small phase 1 study is evaluating the safety and tolerability of blinatumomab combined with nivolumab targeting PD-1 and/or ipilimumab targeting cytotoxic T-lymphocyte antigen 4 (CTLA-4) in patients with R/R B-ALL [167]. Eight patients were enrolled with the median BM blast percentage of $73 \%$. Preliminary results have shown that the CR rate was $80 \%$ while all of them were MRD-negativity among 5 patients treated with blinatumomab and nivolumab. DLT was associated with a grade 4 infusion-related reaction. Another ongoing phase $1 / 2$ study has also shown blinatumomab in combination with PD-1 inhibitor pembrolizumab is effective and safe in patients with R/R B-ALL and high disease burden at baseline [168]. The CR rate was $50 \%$ for four evaluable patients, while this study continues to evaluate efficacy by enrolling patients in the dose-expansion phase. Despite the impressive efficacy of ICI therapy against various solid tumors, the lack of tumor-reactive immune infiltration into tumors is one of the critical 
Table 5 Ongoing clinical trials of blinatumomab in combination with other therapeutic approaches

\begin{tabular}{|c|c|c|c|c|c|c|c|}
\hline $\begin{array}{l}\text { Clinical } \\
\text { Trials.gov } \\
\text { identifier }\end{array}$ & Phase & Patient/Disease & Combination regimen & $\begin{array}{l}\text { Class of } \\
\text { combination } \\
\text { drugs }\end{array}$ & $\begin{array}{l}\text { Estimated } \\
\text { enrollment }\end{array}$ & $\begin{array}{l}\text { Primary } \\
\text { endpoint }\end{array}$ & Status \\
\hline NCT04554485 & 2 & $\begin{array}{l}\text { Adultswith newly diagnosed } \\
\text { Ph-negative CD19+ B-ALL }\end{array}$ & $\begin{array}{l}\text { Single cycle of blinatumomab } \\
\text { followed by high-dose chemo- } \\
\text { therapy in the induction phase }\end{array}$ & Chemotherapy & 45 & CMR & Recruiting \\
\hline NCT03518112 & 2 & $\begin{array}{l}\text { Adults with R/R Ph-negative } \\
\text { B-ALL }\end{array}$ & $\begin{array}{l}\text { Concurrent blinatumomab and } \\
\text { low-intensity chemotherapy }\end{array}$ & Chemotherapy & 44 & EFS & Recruiting \\
\hline NCT03480438 & 2 & $\begin{array}{l}\text { Older adults with newly } \\
\text { diagnosed CD19+ Ph- } \\
\text { negative B-ALL }\end{array}$ & $\begin{array}{l}\text { Sequential dose reduced } \\
\text { chemotherapy and blinatumomab }\end{array}$ & Chemotherapy & 50 & $\begin{array}{l}\text { CHR and } \\
\text { CMR }\end{array}$ & Recruiting \\
\hline NCT02877303 & 2 & $\begin{array}{l}\text { Children and adults with } \\
\text { newly diagnosed B-ALL }\end{array}$ & $\begin{array}{l}\text { Sequential chemotherapy and } \\
\text { blinatumomab }\end{array}$ & Chemotherapy & 60 & RFS & Recruiting \\
\hline NCT03523429 & 2 & $\begin{array}{l}\text { Adults with high-risk CD19+ } \\
\text { Ph-negative B-ALL }\end{array}$ & $\begin{array}{l}\text { Blinatumomab added to } \\
\text { consolidation phase with } \\
\text { chemotherapy }\end{array}$ & Chemotherapy & 38 & $\begin{array}{l}\text { MRD } \\
\text { negative } \\
\text { response }\end{array}$ & Recruiting \\
\hline NCT03541083 & 2 & $\begin{array}{l}\text { Adults with newly diagnosed } \\
\text { CD19+ B-ALL }\end{array}$ & $\begin{array}{l}\text { Blinatumomab added to prephase } \\
\text { and consolidation phase with } \\
\text { chemotherapy }\end{array}$ & Chemotherapy & 80 & $\begin{array}{l}\text { MRD } \\
\text { negative } \\
\text { response }\end{array}$ & Recruiting \\
\hline NCT03367299 & 2 & $\begin{array}{l}\text { Adults with newly diagnosed } \\
\text { or R/R CD19 + Ph-negative B- } \\
\text { ALL }\end{array}$ & $\begin{array}{l}\text { Sequential chemotherapy and } \\
\text { blinatumomab }\end{array}$ & Chemotherapy & 149 & $\begin{array}{l}\text { MRD } \\
\text { negative } \\
\text { response }\end{array}$ & Recruiting \\
\hline NCT03914625 & 3 & $\begin{array}{l}\text { Children and adultswith } \\
\text { newly diagnosed B-ALL }\end{array}$ & $\begin{array}{l}\text { Addition of } 2 \text { cycles of } \\
\text { blinatumomab to standard } \\
\text { chemotherapy }\end{array}$ & Chemotherapy & $6720 a$ & DFS & Recruiting \\
\hline NCT02003222 & 3 & $\begin{array}{l}\text { Adults with newly diagnosed } \\
\text { Ph-negative B-ALL }\end{array}$ & $\begin{array}{l}\text { Sequential chemotherapy and } \\
\text { blinatumomab }\end{array}$ & Chemotherapy & 488 & OS & $\begin{array}{l}\text { Active, not } \\
\text { recruiting }\end{array}$ \\
\hline NCT02744768 & 2 & $\begin{array}{l}\text { Adults with newly diagnosed } \\
\mathrm{Ph}+\mathrm{B}-\mathrm{ALL}\end{array}$ & $\begin{array}{l}\text { Sequential dasatinib and } \\
\text { blinatumomab }\end{array}$ & TKI & 60 & $\begin{array}{l}\text { MRD } \\
\text { negative } \\
\text { response }\end{array}$ & Recruiting \\
\hline NCT02997761 & 2 & $\begin{array}{l}\text { Adults with R/R Ph-negative } \\
\text { B-ALL }\end{array}$ & $\begin{array}{l}\text { Concurrent Ibrutinib and } \\
\text { blinatumomab }\end{array}$ & TKI & 20 & $C R$ & Recruiting \\
\hline NCT04530565 & 3 & $\begin{array}{l}\text { Adults with newly diagnosed } \\
\text { Ph + B-ALL }\end{array}$ & Concurrent TKI and blinatumomab & TKI & 330 & OS & Recruiting \\
\hline NCT04524455 & 1 & Adults with R/R B-ALL & $\begin{array}{l}\text { Blinatumomab in combination } \\
\text { with AMG } 404 \text { (anti-PD-1) }\end{array}$ & $\mathrm{ICl}$ & 21 & $\begin{array}{l}\text { DLTs and } \\
\text { toxicity }\end{array}$ & Recruiting \\
\hline NCT03605589 & 1 & $\begin{array}{l}\text { Children and adults with R/R } \\
\text { CD19+ Ph-negative B-ALL }\end{array}$ & $\begin{array}{l}\text { Blinatumomab in combination } \\
\text { with pembrolizumab (anti-PD-1) }\end{array}$ & $\mathrm{ICl}$ & 24 & $\begin{array}{l}\text { DLTs and } \\
\text { toxicity }\end{array}$ & Suspended \\
\hline NCT02879695 & 1 & $\begin{array}{l}\text { Children and adults with } \\
\text { poor-risk R/R CD19+ B-ALL }\end{array}$ & $\begin{array}{l}\text { Blinatumomab in combination } \\
\text { with nivolumab with or without } \\
\text { ipilimumab (anti-CTLA-4) }\end{array}$ & $\mathrm{ICl}$ & 36 & $\begin{array}{l}\text { Toxicity and } \\
\text { MTD }\end{array}$ & Recruiting \\
\hline NCT03340766 & 1 & Adults R/R DLBCL & $\begin{array}{l}\text { Blinatumomab in combination } \\
\text { with pembrolizumab }\end{array}$ & $\mathrm{ICl}$ & 70 & DLTs & Recruiting \\
\hline NCT03160079 & $1 / 2$ & $\begin{array}{l}\text { Adultswith R/R CD19+ Ph- } \\
\text { negative B-ALL with high } \\
\text { marrow lymphoblasts ( } \geq 50 \%)\end{array}$ & $\begin{array}{l}\text { Blinatumomab in combination } \\
\text { with pembrolizumab }\end{array}$ & $\mathrm{ICl}$ & 24 & ORR & Recruiting \\
\hline NCT03512405 & $1 / 2$ & Adultswith R/R CD19+ B-ALL & $\begin{array}{l}\text { Blinatumomab in combination } \\
\text { with pembrolizumab }\end{array}$ & $\mathrm{ICl}$ & 36 & $\begin{array}{l}\text { Toxicity and } \\
\text { ORR }\end{array}$ & Recruiting \\
\hline NCT04546399 & 2 & $\begin{array}{l}\text { Children and adults with first } \\
\text { relapse CD19+ B-ALL }\end{array}$ & $\begin{array}{l}\text { Blinatumomab in combination } \\
\text { with nivolumab (anti-PD-1) }\end{array}$ & $\mathrm{ICl}$ & 550 & $\begin{array}{l}\text { MRD } \\
\text { negative } \\
\text { second } \\
\text { response } \\
\text { and EFS }\end{array}$ & Recruiting \\
\hline NCT02143414 & 2 & $\begin{array}{l}\text { Older adults with newly } \\
\text { diagnosed Ph-negative B-ALL } \\
\text { (Cohort 1) and Ph + B-ALL } \\
\text { (Cohort 2) }\end{array}$ & $\begin{array}{l}\text { Blinatumomab followed by } \\
\text { chemotherapy (Cohort 1) or } \\
\text { dasatinib followed by } \\
\text { blinatumomab (Cohort 2) }\end{array}$ & $\begin{array}{l}\text { Chemotherapy } \\
\text { or TKI }\end{array}$ & 58 & DLTs and OS & Recruiting \\
\hline NCT03263572 & 2 & Adults with $\mathrm{Ph}+\mathrm{B}-\mathrm{ALL}$ & Concurrent blinatumomab, & Chemotherapy & 60 & CMR, ORR, & Recruiting \\
\hline
\end{tabular}


Table 5 Ongoing clinical trials of blinatumomab in combination with other therapeutic approaches (Continued)

\begin{tabular}{|c|c|c|c|c|c|c|c|}
\hline $\begin{array}{l}\text { Clinical } \\
\text { Trials.gov } \\
\text { identifier }\end{array}$ & Phase & Patient/Disease & Combination regimen & $\begin{array}{l}\text { Class of } \\
\text { combination } \\
\text { drugs }\end{array}$ & $\begin{array}{l}\text { Estimated } \\
\text { enrollment }\end{array}$ & $\begin{array}{l}\text { Primary } \\
\text { endpoint }\end{array}$ & Status \\
\hline & & & chemotherapy, and ponatinib & and TKI & & $\begin{array}{l}\text { RFS, EFS, and } \\
\text { OS }\end{array}$ & \\
\hline NCT03147612 & 2 & Adults with Ph + B-ALL & $\begin{array}{l}\text { Sequential low-Intensity chemo- } \\
\text { therapy and ponatinib followed } \\
\text { by blinatumomab and ponatinib }\end{array}$ & $\begin{array}{l}\text { Chemotherapy } \\
\text { and TKI }\end{array}$ & 60 & $\begin{array}{l}\text { CMR and } \\
\text { ORR }\end{array}$ & Recruiting \\
\hline NCT02568553 & 1 & Adults with R/R CD19+ B-NHL & $\begin{array}{l}\text { Concurrent lenalidomide and } \\
\text { blinatumomab }\end{array}$ & Others & 44 & Toxicity & Recruiting \\
\hline NCT03751709 & 1 & $\begin{array}{l}\text { Adults ( } \geq 18 \text { years) with } R / R \\
\text { CD19+ B-ALL }\end{array}$ & $\begin{array}{l}\text { Blinatumomab in combination } \\
\text { with HLA-Mismatched Cellular } \\
\text { Therapy }\end{array}$ & Others & 10 & DLTs & Recruiting \\
\hline NCT03739814 & 2 & $\begin{array}{l}\text { Adults with newly diagnosed } \\
\text { or R/R CD22+ Ph-negative B- } \\
\text { ALL }\end{array}$ & $\begin{array}{l}\text { Inotuzumab ozogamicin followed } \\
\text { by blinatumomab }\end{array}$ & Others & 64 & EFS & Recruiting \\
\hline NCT03982992 & 2 & $\begin{array}{l}\text { Adults with treatment- } \\
\text { resistant MC or MRD of } \\
\text { CD19+ B-ALL after HSCT }\end{array}$ & $\begin{array}{l}\text { Blinatumomab in combination } \\
\text { with donor lymphocyte infusion }\end{array}$ & Others & 12 & Toxicity & Recruiting \\
\hline
\end{tabular}

Ph Philadelphia chromosome, CR Complete remission, CHR Complete hematologic remission, MRD Minimal residual disease, DLTs Dose-limiting toxicities, ORR Overall response rate, EFS Event-free survival, MTD Maximum tolerated dose, RFS Relapse-free survival, OS Overall survival, DFS Disease free survival, MC Mixed chimerism, DLBCL Diffuse large B-cell lymphoma, CMR Complete molecular response, HSCT Allogeneic hematopoietic stem cell transportation

factors for the limited response rates. BiTE therapy can redirect large numbers of cytotoxic $\mathrm{T}$ cells to the tumor site to overcome this limitation and exert antigenspecific anti-tumor immunity. Furtherly, the therapeutic efficacy will be amplified by the addition of ICIs that facilitate a favorable immune profile and immune function of $\mathrm{T}$ cells by blocking immune checkpoint pathways.

Clinical trials concerning blinatumomab in combination with other therapeutic approaches involving immunomodulatory drug (lenalidomide), ADC (inotuzumab ozogamicin), and adoptive cellular therapy (donor lymphocyte infusion) are also in progress, which is summarized in Table 5.

\section{Beyond CD3 T cells}

According to the diversity of expressed TCR, T cells are mainly divided into $\alpha \beta$ and $\gamma \delta$ T cells. Current cancer immunotherapies such as ICI therapy focus mostly on the MHC-restricted $\alpha \beta \mathrm{T}$ cells, while $\gamma \delta \mathrm{T}$ cells also present potent anti-tumor activity independently from $\mathrm{MHC}$ restriction, and thus immunotherapy based on V $\gamma 9 \mathrm{~V} \delta 2 \mathrm{~T}$ cells, the predominant subtypes of $\gamma \delta \mathrm{T}$ cells, enable favorable clinical outcomes in various cancers with low toxicity $[169,170]$. Bispecific $\gamma \delta \mathrm{T}$ cell engager is being developed, the antibody targeting $\mathrm{V} \gamma 9 \mathrm{~V} \delta 2$ on $\gamma \delta$ $\mathrm{T}$ cells and EGFR on tumors cells was demonstrated to induce strong activation of $\mathrm{V} \gamma 9 \mathrm{~V} \delta 2 \mathrm{~T}$ cells and cytotoxic lysis of tumor cells in a mouse xenograft model [171]. Further studies are needed to evaluate whether the BiTE for the recruitment of $\gamma \delta \mathrm{T}$ cells is more effective than classical BiTE targeting CD3 that is expressed on both $\alpha \beta$ and $\gamma \delta \mathrm{T}$ cells [172]. In addition to T cells, NK cells are also essential effector cells as a part of innate immunity that contribute to anti-tumor responses, therefore, considerable interest has recently focused on the potential of NK cells for cancer immunotherapies [173]. Bispecific killer cell engager (BiKE) that ligate CD16 on NK cells and a tumor antigen on tumor cells has been developed to activate NK cells and induce target cell lysis, to further improve activation, expansion, and survival of NK cells, a modified IL-15 crosslinker is infused into $\mathrm{BiKE}$ to create trispecific killer engager (TriKE) which has shown superior anti-tumor activity compared with BiKE [174, 175] (Fig. 3). A phase1/2 clinical trial of GTB-3550 (CD16/IL-15/CD33) TriKE for the treatment of CD33-expressing high-risk myelodysplastic syndromes, R/R ALL, or advanced systemic mastocytosis is ongoing (NCT03214666). A new generation of trifunctional NK-cell engager (NKCE) targeting two activating receptors NKp46 and CD16 on NK cells and a specific antigen on tumor cells has been reported to have more potent anti-tumor activity than clinical therapeutic antibodies in vitro and in vivo [176]. Moreover, natural killer $\mathrm{T}$ cells (NKT) cells, a kind of innate-like lymphocytes, are quickly gaining attention as carries for CAR therapy termed as CAR-NKT cells which are currently being investigated in phase 1 clinical trial for patients with $R / R$ neuroblastoma, preliminary results have shown CARNKT cells were safe and effective and can be applied to treat more patients (NCT03294954) [177]. Macrophages, another key component of innate immunity, can also be utilized as targeted immune effector cells in innate cellbased immunotherapies, the CAR macrophages (CARMs) construct has been developed and has displayed 
excellent efficacy, reducing tumor burden and extending survival time in two solid tumor xenograft mouse models, as only one injection is needed [178]. Consequently, cancer immunotherapies for reactivating innate immunity hold great promise through targeting innate cells or innate-like cells such as NK cells, macrophages, NKT cells, and $\gamma \delta \mathrm{T}$ cells, complement or even replace current therapies.

\section{Conclusions}

As the landscape of $\mathrm{T}$ cells and their role in anti-cancer immunity evolve, the development of T-cell-based immunotherapies has made a huge breakthrough in the last decade. In particular, the BiTE antibodies redirecting $\mathrm{T}$ cells to kill tumor cells have exhibited favorable clinical outcomes in R/R hematopoietic malignancies, as well as in solid tumors with preliminary evidence of clinical benefits. However, there remains a considerable number of patients that are resistant to the BiTE therapy and can not achieve durable responses. Current research has demonstrated that antigen loss and immunosuppressive factors, especially upregulation of inhibitory immune checkpoint molecules, are the two main mechanisms responsible for treatment failure. Therefore, strategies regarding improving BiTE constructs and developing novel $\mathrm{T}$ cell-engager antibodies with higher antigen avidities and multiple targets are currently being investigated in a series of preclinical and clinical studies, as well as combination therapies with BiTE antibodies and other therapeutic approaches. In addition to $\mathrm{T}$ cells, innate cell or innate-like cell engagers focusing on innate immunity are gaining increasing attention and have shown potent anti-tumor activity in various cancers, which reflects an orientation toward the future.

\section{Acknowledgements}

I would like to thank my supervisor, Dr. Meng, for her guidance through each stage of the process.

\section{Authors' contributions}

Shujie Zhou: Contributed to Writing - Original Draft, Investigation, and Resources. Mingguo Liu: Contributed to Resources. Fei Ren: Contributed to Resources. Jinming Yu: Contributed to the Writing - Review \& Editing and Funding acquisition. Xiangjiao Meng: Contributed to Study design, Supervision, and Writing - Review \& Editing. All authors read and approved the final manuscript

\section{Funding}

The study was funded by the National Natural Science Foundation of China (No.81972796 and 81972863), the National Key Research and Development Project (2018YFC1313200), the Innovation Project of Shandong Academy of Medical Sciences (2019-04), the Natural Science Foundation of Shandong (No.ZR2019MH010), and the Academic Promotion Program of Shandong First Medical University (2019ZL002).

Availability of data and materials Not applicable.

\section{Declarations}

Ethics approval and consent to participate

Not applicable.

\section{Consent for publication}

Not applicable.

\section{Competing interests}

The authors declare that they have no known competing financial interests or personal relationships that could have appeared to influence the work reported in this paper.

\section{Author details}

${ }^{1}$ Cheeloo College of Medicine, Shandong University, Jinan, Shandong, China. ${ }^{2}$ Department of Radiation Oncology, Shandong Cancer Hospital affiliated to Shandong First Medical University, Jinan, Shandong, China. ${ }^{3}$ Department of Oncology, Yuncheng Honesty Hospital, Heze, Shandong, China. ${ }^{4}$ Department of Radiation Oncology, Shandong Cancer Hospital affiliated to Shandong University, Jinan, Shandong, China.

Received: 25 January 2021 Accepted: 10 May 2021

Published online: 26 May 2021

\section{References}

1. Baumeister SH, Freeman GJ, Dranoff G, Sharpe AH. Coinhibitory pathways in immunotherapy for cancer. Annu Rev Immunol. 2016;34:539-73.

2. June $\mathrm{CH}$, Connor RSO, Kawalekar OU, Ghassemi S, Milone MC. CAR T cell immunotherapy for human cancer. Science. 2018;359:1361-5.

3. Goebeler M, Bargou RC. T cell-engaging therapies - BiTEs and beyond. Nat Rev Clin Oncol. 2020;17:418-34

4. Borghaei H, Paz-Ares L, Horn L, Spigel DR, Steins M, Ready NE, et al. Nivolumab versus docetaxel in advanced nonsquamous non-small-cell lung cancer. New Engl J Med. 2015;373:1627-39.

5. Brahmer J, Reckamp KL, Baas P, Crinò L, Eberhardt WEE, Poddubskaya E, et al. Nivolumab versus docetaxel in advanced squamous-cell non-smallcell lung cancer. New Engl J Med. 2015;373:123-35.

6. Hamid O, Robert C, Daud A, Hodi FS, Hwu WJ, Kefford R, et al. Safety and tumor responses with lambrolizumab (anti-PD-1) in melanoma. N Engl J Med. 2013;369:134-44.

7. Robert C, Schachter J, Long GV, Arance A, Grob JJ, Mortier L, et al. Pembrolizumab versus ipilimumab in advanced melanoma. New Engl J Med. 2015;372:2521-32.

8. Friedrich M, Jasinski-Bergner S, Lazaridou M, Subbarayan K, Massa C, Tretbar $\mathrm{S}$, et al. Tumor-induced escape mechanisms and their association with resistance to checkpoint inhibitor therapy. Cancer Immunol Immunother. 2019;68:1689-700

9. Garris CS, Arlauckas SP, Kohler RH, Trefny MP, Garren S, Piot C, et al. Successful anti-PD-1 cancer immunotherapy requires $T$ cell-dendritic cell crosstalk involving the cytokines IFN- $\gamma$ and IL-12. Immunity. 2018;49:11481161.e7.

10. Singh AK, McGuirk JP. CAR T cells: continuation in a revolution of immunotherapy. Lancet Oncol. 2020;21:e168-78.

11. Santomasso B, Bachier C, Westin J, Rezvani K, Shpall EJ. The other side of CAR T-cell therapy: cytokine release syndrome, neurologic toxicity, and financial burden. Am Soc Clin Oncol Educ Book. 2019;39:433-44.

12. Suurs FV, Lub-de Hooge MN, de Vries EGE, de Groot DJA. A review of bispecific antibodies and antibody constructs in oncology and clinical challenges. Pharmacol Therapeut. 2019;201:103-19.

13. Rudolph MG, Stanfield RL, Wilson IA. How TCRs bind MHCs, peptides, and coreceptors. Annu Rev Immunol. 2006;24:419-66.

14. Thakur A, Huang M, Lum LG. Bispecific antibody based therapeutics: strengths and challenges. Blood Rev. 2018;32:339-47.

15. Wang TT, Ravetch JV. Functional diversification of IgGs through FC glycosylation. J Clin Invest. 2019;129:3492-8

16. Löffler A, Kufer P, Lutterbüse R, Zettl F, Daniel PT, Schwenkenbecher JM et al. A recombinant bispecific single-chain antibody, CD19 x CD3, induces rapid and high lymphoma-directed cytotoxicity by unstimulated $T$ lymphocytes. Blood. 2000;95:2098-103. 
17. DuPage M, Mazumdar C, Schmidt LM, Cheung AF, Jacks T. Expression of tumour-specific antigens underlies cancer immunoediting. Nature. 2012;482: 405-9.

18. Alspach E, Lussier DM, Miceli AP, Kizhvatov I, DuPage M, Luoma AM, et al. MHC-II neoantigens shape tumour immunity and response to immunotherapy. Nature. 2019;574:696-701.

19. Yamamoto K, Venida A, Yano J, Biancur DE, Kakiuchi M, Gupta S, et al. Autophagy promotes immune evasion of pancreatic cancer by degrading MHC-I. Nature. 2020;581:100-5.

20. Smith-Garvin JE, Koretzky GA, Jordan MS. T cell activation. Annu Rev Immunol. 2009;27:591-619.

21. Klinger M, Benjamin J, Kischel R, Stienen S, Zugmaier G. Harnessing T cells to fight cancer with BiTE ${ }^{\oplus}$ antibody constructs - past developments and future directions. Immunol Rev. 2016;270:193-208.

22. Offner S, Hofmeister R, Romaniuk A, Kufer P, Baeuerle PA. Induction of regular cytolytic T cell synapses by bispecific single-chain antibody constructs on $\mathrm{MHC}$ class I-negative tumor cells. Mol Immunol. 2006:43:763-71.

23. Dreier T, Lorenczewski G, Brandl C, Hoffmann P, Syring U, Hanakam F, et al. Extremely potent, rapid and costimulation-independent cytotoxic T-cell response against lymphoma cells catalyzed by a single-chain bispecific antibody. Int J Cancer. 2002;100:690-7.

24. Bromley SK, Burack WR, Johnson KG, Somersalo K, Sims TN, Sumen C, et al. The immunological synapse. Annu Rev Immunol. 2001;19:375-96.

25. Wolf E, Hofmeister R, Kufer P, Schlereth B, Baeuerle PA. BiTEs: bispecific antibody constructs with unique anti-tumor activity. Drug Discov Today. 2005;10:1237-44.

26. Wang K, Wei G, Liu D. CD19: a biomarker for B cell development, lymphoma diagnosis and therapy. Exp Hematol Oncol. 2012;1:36

27. Engel P, Zhou L, Ord DC, Sato S, Koller B, Tedder TF. Abnormal B lymphocyte delevopment, activation, and differentiation in mice that lack or overexpress the CD19 signal transduction molecule. Immunity. 1995;3:39-50.

28. Nagorsen D, Kufer P, Baeuerle PA, Bargou R. Blinatumomab: a historical perspective. Pharmacol Therapeut. 2012;136:334-42.

29. Hoelzer D, Bassan R, Dombret H, Fielding A, Ribera JM, Buske C. Acute lymphoblastic leukaemia in adult patients: ESMO clinical practice guidelines for diagnosis, treatment and follow-up. Ann Oncol. 2016;27:v69-82.

30. Einsele H, Borghaei H, Orlowski RZ, Subklewe M, Roboz GJ, Zugmaier G, et al. The BiTE (bispecific T-cell engager) platform: development and future potential of a targeted immuno-oncology therapy across tumor types. Cancer-Am Cancer Soc. 2020:126:3192-201.

31. Liu D, Zhao J, Song Y, Luo X, Yang T. Clinical trial update on bispecific antibodies, antibody-drug conjugates, and antibody-containing regimens for acute lymphoblastic leukemia. J Hematol Oncol. 2019;12:15.

32. Topp MS, Kufer P, Gokbuget N, Goebeler M, Klinger M, Neumann S, et al. Targeted therapy with the T-cell-engaging antibody blinatumomab of chemotherapy-refractory minimal residual disease in B-lineage acute lymphoblastic leukemia patients results in high response rate and prolonged leukemia-free survival. J Clin Oncol. 2011;29:2493-8.

33. Topp MS, Gökbuget N, Zugmaier G, Degenhard E, Goebeler M, Klinger M, et al. Long-term follow-up of hematologic relapse-free survival in a phase 2 study of blinatumomab in patients with MRD in B-lineage ALL. Blood. 2012; 120:5185-7.

34. Gökbuget $N$, Zugmaier $G$, Klinger $M$, Kufer $P$, Stelljes $M$, Viardot $A$, et al. Long-term relapse-free survival in a phase 2 study of blinatumomab for the treatment of patients with minimal residual disease in B-lineage acute lymphoblastic leukemia. Haematologica. 2017;102:e132-5.

35. Gökbuget N, Dombret H, Bonifacio M, Reichle A, Graux C, Faul C, et al. Blinatumomab for minimal residual disease in adults with B-cell precursor acute lymphoblastic leukemia. Blood. 2018;131:1522-31.

36. Gökbuget N, Zugmaier G, Dombret H, Stein A, Bonifacio M, Graux C, et al. Curative outcomes following blinatumomab in adults with minimal residual disease B-cell precursor acute lymphoblastic leukemia. Leuk Lymphoma. 2020;61:2665-73.

37. Kiyoi H, Morris JD, Oh I, Maeda Y, Minami H, Miyamoto T, et al. Phase 1b/2 study of blinatumomab in Japanese adults with relapsed/refractory acute lymphoblastic leukemia. Cancer Sci. 2020;111:1314-23.

38. Topp MS, Gökbuget N, Zugmaier G, Klappers P, Stelljes M, Neumann S, et al. Phase II trial of the anti-CD19 bispecific T cell-engager blinatumomab shows hematologic and molecular remissions in patients with relapsed or refractory B-precursor acute lymphoblastic leukemia. J Clin Oncol. 2014;32: 4134-40.
39. Topp MS, Gökbuget N, Stein AS, Zugmaier G, O'Brien S, Bargou RC, et al. Safety and activity of blinatumomab for adult patients with relapsed or refractory B-precursor acute lymphoblastic leukaemia: a multicentre, singlearm, phase 2 study. Lancet Oncol. 2015:16:57-66.

40. Kantarjian H, Stein A, Gökbuget N, Fielding AK, Schuh AC, Ribera J, et al. Blinatumomab versus chemotherapy for advanced acute lymphoblastic leukemia. New Engl J Med. 2017;376:836-47.

41. Locatelli F, Zugmaier G, Mergen N, Bader P, Jeha S, Schlegel $P$, et al. Blinatumomab in pediatric patients with relapsed/refractory acute lymphoblastic leukemia: results of the RIALTO trial, an expanded access study. Blood Cancer J. 2020;10:1-5.

42. von Stackelberg A, Locatelli F, Zugmaier G, Handgretinger R, Trippett TM,

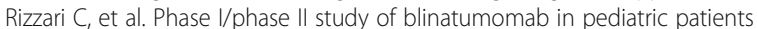
with relapsed/refractory acute lymphoblastic leukemia. J Clin Oncol. 2016; 34:4381-9.

43. Martinelli G, Boissel N, Chevallier P, Ottmann O, Gökbuget N, Topp MS, et al. Complete hematologic and molecular response in adult patients with relapsed/refractory Philadelphia chromosome-positive B-precursor acute lymphoblastic leukemia following treatment with blinatumomab: results from a phase II, single-arm, multicenter study. J Clin Oncol. 2017;35:1795-802.

44. Goebeler M, Knop S, Viardot A, Kufer P, Topp MS, Einsele H, et al. Bispecific T-cell engager (BiTE) antibody construct blinatumomab for the treatment of patients with relapsed/refractory non-Hodgkin lymphoma: final results from a phase I study. J Clin Oncol. 2016;34:1104-11.

45. Dufner V, Sayehli CM, Chatterjee M, Hummel HD, Gelbrich G, Bargou RC, et al. Long-term outcome of patients with relapsed/refractory B-cell nonHodgkin lymphoma treated with blinatumomab. Blood Adv. 2019:3:2491-8.

46. Coyle L, Morley NJ, Rambaldi A, Mason KD, Verhoef G, Furness CL, et al. Open-label, phase 2 study of blinatumomab as second salvage therapy in adults with relapsed/refractory aggressive B-cell non-Hodgkin lymphoma. Leuk Lymphoma. 2020;61:2103-12.

47. Viardot A, Goebeler M, Hess G, Neumann S, Pfreundschuh M, Adrian N, et al Phase 2 study of the bispecific T-cell engager (BiTE) antibody blinatumomab in relapsed/refractory diffuse large B-cell lymphoma. Blood. 2016;127:1410-6.

48. Malik H, Buelow B, Rangaswamy U, Balasubramani A, Boudreau A, Dang K, et al. TNB-486, a novel fully human bispecific CD19 x CD3 antibody that kills CD19-positive tumor cells with minimal cytokine secretion. Blood. 2019;134: 4070

49. Izhak L, Cullen DE, Elgawly M, Luistro L, Johnson S, Bald J, et al. Abstract 3636: potent antitumor activity of duvortuxizumab, a CD19 x CD3 DART molecule, in lymphoma models. Cancer Res. 2017;77:3636.

50. Reusch U, Duell J, Ellwanger K, Herbrecht C, Knackmuss SH, Fucek I, et al. A tetravalent bispecific TandAb (CD19/CD3), AFM11, efficiently recruits T cells for the potent lysis of CD19(+) tumor cells. Mabs-Austin. 2015;7:584-604.

51. Crocker PR, Paulson JC, Varki A. Siglecs and their roles in the immune system. Nat Rev Immunol. 2007;7:255-66.

52. Ravandi $F$, Walter RB, Subklewe $M$, Buecklein $V_{\text {, Jongen-Lavrencic } M}$ Paschka P, et al. Updated results from phase I dose-escalation study of AMG 330, a bispecific T-cell engager molecule, in patients with relapsed/ refractory acute myeloid leukemia (R/R AML). J Clin Oncol. 2020;38:7508.

53. Subklewe M, Stein A, Walter RB, Bhatia R, Wei AH, Ritchie $D$, et al. Preliminary results from a phase 1 first-in-human study of AMG 673, a novel half-life extended (HLE) anti-CD33/CD3 BiTE ${ }^{\oplus}$ (bispecific T-cell engager) in patients with relapsed/refractory (R/R) acute myeloid leukemia (AML). Blood. 2019;134:833

54. Nair-Gupta P, Diem M, Reeves D, Wang W, Schulingkamp R, Sproesser K, et al. A novel C2 domain binding CD33xCD3 bispecific antibody with potent T-cell redirection activity against acute myeloid leukemia. Blood Adv. 2020;4:906-19.

55. Anti-CD33/CD3 bispecific antibody GEM 333. Available at: https://www.ca ncer.gov/publications/dictionaries/cancer-drug/def/anti-cd33-cd3bispecific-antibody-gem-333. Accessed 20 Dec 2020.

56. Westervelt $\mathrm{P}$, Cortes JE, Altman JK, Long M, Oehler VG, Gojo I, et al. Phase 1 first-in-human trial of AMV564, a bivalent bispecific (2:2) CD33/CD3 T-cell engager, in patients with relapsed/refractory acute myeloid leukemia (AML). Blood. 2019;134:834.

57. Carpenter RO, Evbuomwan MO, Pittaluga S, Rose JJ, Raffeld M, Yang S, et al. B-cell maturation antigen is a promising target for adoptive T-cell therapy of multiple myeloma. Clin Cancer Res. 2013;19:2048-60. 
58. Topp MS, Duell J, Zugmaier G, Attal M, Moreau P, Langer C, et al. Anti-B-cell maturation antigen BiTE molecule AMG 420 induces responses in multiple myeloma. J Clin Oncol. 2020;38:775-83.

59. Harrison SJ, Minnema MC, Lee HC, Spencer A, Kapoor P, Madduri D, et al. A phase 1 first in human $(F \mid H)$ study of AMG 701, an anti-B-cell maturation antigen (BCMA) half-life extended (HLE) BiTE ${ }^{\oplus}$ (bispecific T-cell engager) molecule, in relapsed/refractory (RR) multiple myeloma (MM). Blood. 2020; 136:28-9.

60. Pillarisetti K, Powers G, Luistro L, Babich A, Baldwin E, Li Y, et al. Teclistamab is an active $T$ cell-redirecting bispecific antibody against B-cell maturation antigen for multiple myeloma. Blood Adv. 2020;4:4538-49.

61. Madduri D, Rosko A, Brayer J, Zonder J, Bensinger WI, Li J, et al. REGN5458, a BCMA x CD3 bispecific monoclonal antibody, induces deep and durable responses in patients with relapsed/refractory multiple myeloma (RRMM). Blood. 2020;136:41-2.

62. Costa $L$, Wong SW, Bermúdez A, de la Rubia J, Mateos M, Ocio EM, et al. First clinical study of the B-cell maturation antigen (BCMA) $2+1 \mathrm{~T}$ cell engager (TCE) CC-93269 in patients (Pts) with relapsed/refractory multiple myeloma (RRMM): interim results of a phase 1 multicenter trial. Blood. 2019; 134:143.

63. Raje NS, Jakubowiak A, Gasparetto C, Cornell RF, Krupka HI, Navarro D, et al. Safety, clinical activity, pharmacokinetics, and pharmacodynamics from a phase I study of PF-06863135, a B-cell maturation antigen (BCMA)-CD3 bispecific antibody, in patients with relapsed/refractory multiple myeloma (RRMM). Blood. 2019;134:1869.

64. Rodriguez C, D'Souza A, Shah N, Voorhees PM, Buelow B, Vij R, et al. Initial results of a phase I study of TNB-383B, a BCMA x CD3 bispecific T-cell redirecting antibody, in relapsed/refractory multiple myeloma. Blood. 2020; 136:43-4.

65. Hutchings M, Mous R, Clausen MR, Johnson P, Linton KM, Chamuleau MED, et al. Subcutaneous epcoritamab induces complete responses with an encouraging safety profile across relapsed/refractory B-cell non-Hodgkin lymphoma subtypes, including patients with prior CAR-T therapy: updated dose escalation data. Blood. 2020;136:45-6.

66. Bannerji R, Allan JN, Arnason JE, Brown JR, Advani R, Ansell SM, et al. Odronextamab (REGN1979), a human CD20 x CD3 bispecific antibody, induces durable, complete responses in patients with highly refractory Bcell non-Hodgkin lymphoma, including patients refractory to CAR T therapy. Blood. 2020;136:42-3.

67. Assouline SE, Kim WS, Sehn LH, Schuster SJ, Cheah CY, Nastoupil LJ, et al. Mosunetuzumab shows promising efficacy in patients with multiply relapsed follicular lymphoma: updated clinical experience from a phase I dose-escalation trial. Blood. 2020;136:42-4.

68. Patel K, Michot J, Chanan-Khan AA, Salles GA, Cartron G, Peyrade F, et al. Preliminary safety and anti-tumor activity of XmAb13676, an anti-CD20 X anti-CD3 bispecific antibody, in patients with relapsed/refractory nonHodgkin's lymphoma and chronic lymphocytic leukemia. Blood. 2019;134: 4079 .

69. Hutchings M, Carlo-Stella C, Bachy E, Offner FC, Morschhauser F, Crump M, et al. Glofitamab step-up dosing induces high response rates in patients with hard-to-treat refractory or relapsed non-Hodgkin lymphoma. Blood. 2020;136:46-8

70. IGM Biosciences Presents First Clinical Data from IGM-2323 in NonHodgkin's Lymphoma at 2020 ASH Annual Meeting. Available at: https:// igmbio.com/2020/12/05/igm-biosciences-presents-first-clinical-data-fromigm-2323-in-non-hodgkins-lymphoma-at-2020-ash-annual-meeting/. Accessed 15 Mar 2021

71. Garfall AL, Usmani SZ, Mateos M, Nahi H, van de Donk NWCJ, San-Miguel JF, et al. Updated phase 1 results of teclistamab, a B-cell maturation antigen $(B C M A) \times C D 3$ bispecific antibody, in relapsed and/or refractory multiple myeloma (RRMM). Blood. 2020;136:27.

72. Pfizer Reports Positive Clinical Data for BCMA-CD3 Bispecific Antibody (PF06863135) in Multiple Myeloma. Available at: https://stockhouse.com/news/ press-releases/2020/12/07/pfizer-reports-positive-clinical-data-for-bcma-cd3bispecific-antibody-pf. Accessed 16 Mar 2021.

73. Cohen AD, Harrison SJ, Krishnan A, Fonseca R, Forsberg PA, Spencer A, et al. Initial clinical activity and safety of BFCR4350A, a FCRH5/CD3 T-cellengaging bispecific antibody, in relapsed/refractory multiple myeloma. Blood. 2020:136:42-3.

74. Chari A, Berdeja JG, Oriol A, van de Donk NWCJ, Rodriguez P, Askari E, et al. A phase 1, first-in-human study of talquetamab, a $\mathrm{G}$ protein-coupled receptor family C group 5 member D (GPRC5D) x CD3 bispecific antibody, in patients with relapsed and/or refractory multiple myeloma (RRMM). Blood. 2020;136:40-1.

75. Aldoss I, Uy GL, Vey N, Emadi A, Sayre PH, Walter RB, et al. Flotetuzumab as salvage therapy for primary induction failure and early relapse acute myeloid leukemia. Blood. 2020;136:16-8.

76. Mhawech-Fauceglia P, Zhang S, Terracciano L, Sauter G, Chadhuri A, Herrmann FR, et al. Prostate-specific membrane antigen (PSMA) protein expression in normal and neoplastic tissues and its sensitivity and specificity in prostate adenocarcinoma: an immunohistochemical study using mutiple tumour tissue microarray technique. Histopathology. 2007;50:472-83.

77. Hummel H, Kufer P, Grüllich C, Deschler-Baier B, Chatterjee M, Goebeler M, et al. Phase I study of pasotuxizumab (AMG 212/BAY 2010112), a PSMAtargeting BiTE (bispecific T-cell engager) immune therapy for metastatic castration-resistant prostate cancer (mCRPC). J Clin Oncol. 2020;38:124.

78. Tran B, Horvath L, Dorff T, Rettig M, Lolkema MP, Machiels J, et al. Results from a phase I study of AMG 160, a half-life extended (HLE), PSMA-targeted, bispecific T-cell engager (BiTE ${ }^{\circledast}$ ) immune therapy for metastatic castrationresistant prostate cancer (mCRPC). Ann Oncol. 2020;31(suppl_4):S507-49.

79. Bendell JC, Fong L, Stein MN, Beer TM, Ross A, Gao X, et al. First-in-human phase I study of HPN424, a tri-specific half-life extended PSMA-targeting Tcell engager in patients with metastatic castration-resistant prostate cancer (mCRPC). J Clin Oncol. 2020;38:5552.

80. Rosenthal MA, Balana C, van Linde ME, Sayehli C, Fiedler WM, Wermke M, et al. ATIM-49 (LTBK-01). AMG 596, AMG 596, a novel anti-EGFRvIll bispecific T cell engager (BITE ${ }^{\circledast}$ ) molecule for the treatment of glioblastoma (GBM): planned interim analysis in recurrent GBM (RGBM). Neuro-Oncology. 2019; 21:vi283.

81. Amgen. Amgen Presents First Clinical Data for AMG 757 at SITC 2020. https://www.amgen.com/newsroom/press-releases/2020/11/amgenpresents-first-clinical-data-for-amg-757-at-sitc-2020. Accessed 12 Dec 2020.

82. Chao J, Buxó E, Cervantes A, Dayyani F, Lima CMSP, Greil R, et al. Trial in progress: a phase I study of AMG 199, a half-life extended bispecific T-cell engager (HLE BiTE) immune therapy, targeting MUC17 in patients with gastric and gastroesophageal junction (G/GEJ) cancer. J Clin Oncol. 2020;38: TPS4649.

83. Bailis JM, Lutterbuese P, Thomas O, Locher K, Harrold J, Boyle M, et al. Abstract 3364: preclinical evaluation of BiTE®immune therapy targeting MUC17 or CLDN18.2 for gastric cancer. Cancer Res. 2020;80:3364.

84. Piha-Paul S, Starodub A, Karim R, Shafique M, Suarez GT, Ruegg C, et al. 372 single-agent anti-tumor activity in relapsed/refractory solid tumors: interim data from the phase 1 solid tumor trial of AMV564, a novel T-cell engager. J Immunother Cancer. 2020;8:A397.

85. Tabernero J, Melero I, Ros W, Argiles G, Marabelle A, Rodriguez-Ruiz ME, et al. Phase la and Ib studies of the novel carcinoembryonic antigen (CEA) T-cell bispecific (CEA CD3 TCB) antibody as a single agent and in combination with atezolizumab: preliminary efficacy and safety in patients with metastatic colorectal cancer (mCRC). J Clin Oncol. 2017;35:3002.

86. Yu S, Zhang J, Yan Y, Yao X, Fang $L$, Xiong $H$, et al. A novel asymmetrical anti-HER2/CD3 bispecific antibody exhibits potent cytotoxicity for HER2positive tumor cells. J Exp Clin Cancer Res. 2019;38:355.

87. Song L, Xue J, Zhang J, Li S, Liu D, Zhou T. Mechanistic prediction of first-inhuman dose for bispecific CD3/EpCAM T-cell engager antibody M701, using an integrated PK/PD modeling method. Eur J Pharm Sci. 2021;158:105584.

88. Ishiguro T, Sano Y, Komatsu S, Kamata-Sakurai M, Kaneko A, Kinoshita Y, et al. An anti-glypican 3/CD3 bispecific T cell-redirecting antibody for treatment of solid tumors. Sci Transl Med. 2017;9:eaal4291.

89. Moore PA, Shah K, Yang Y, Alderson R, Roberts P, Long V, et al. Development of MGD007, a gpA33 x CD3-bispecific DART protein for T-cell immunotherapy of metastatic colorectal cancer. Mol Cancer Ther. 2018;17: $1761-72$.

90. Hernandez-Hoyos G, Sewell T, Bader R, Bannink J, Chenault RA, Daugherty M, et al. MOR209/ES414, a novel bispecific antibody targeting PSMA for the treatment of metastatic castration-resistant prostate cancer. Mol Cancer Ther. 2016;15:2155-65.

91. Xu H, Cheng M, Guo H, Chen Y, Huse M, Cheung NV. Retargeting T cells to GD2 pentasaccharide on human tumors using bispecific humanized antibody. Cancer Immunol Res. 2015;3:266-77.

92. Gan HK, Cvrljevic AN, Johns TG. The epidermal growth factor receptor variant III (EGFRvIII): where wild things are altered. FEBS J. 2013;280: 5350-70. 
93. Aldoss I, Song J, Stiller T, Nguyen T, Palmer J, O'Donnell M, et al. Correlates of resistance and relapse during blinatumomab therapy for relapsed/ refractory acute lymphoblastic leukemia. Am J Hematol. 2017;92:858-65.

94. Zhao Y, Aldoss I, Qu C, Crawford JC, Gu Z, Allen EK, et al. Tumor-intrinsic and -extrinsic determinants of response to blinatumomab in adults with BALL. Blood. 2021;137:471-84.

95. Park JH, Rivière I, Gonen M, Wang X, Sénéchal B, Curran KJ, et al. Long-term follow-up of CD19 CAR therapy in acute lymphoblastic leukemia. New Engl J Med. 2018;378:449-59.

96. King AC, Bolanos R, Velasco K, Tu H, Zaman F, Geyer MB, et al. Real world chart review of blinatumomab to treat patients with high disease burden of relapsed or refractory B-cell precursor acute lymphoblastic leukemia. Blood. 2019;134:5079.

97. Brown P, Zugmaier G, Gore L, Tuglus CA, Stackelberg A. Day 15 bone marrow minimal residual disease predicts response to blinatumomab in relapsed/refractory paediatric B-ALL. Brit J Haematol. 2019;188:e36-9.

98. Walker AJ, Majzner RG, Zhang L, Wanhainen K, Long AH, Nguyen SM, et al. Tumor antigen and receptor densities regulate efficacy of a chimeric antigen receptor targeting anaplastic lymphoma kinase. Mol Ther. 2017;25: 2189-201.

99. Watanabe K, Terakura S, Martens AC, van Meerten T, Uchiyama S, Imai M, et al. Target antigen density governs the efficacy of anti-CD20-CD28-CD3 $\zeta$ chimeric antigen receptor-modified effector CD8+ T cells. J Immunol. 2015; 194:911-20.

100. Krupka C, Kufer P, Kischel R, Zugmaier G, Lichtenegger FS, Köhnke T, et al. Blockade of the PD-1/PD-L1 axis augments lysis of AML cells by the CD33/ CD3 BiTE antibody construct AMG 330: reversing a T-cell-induced immune escape mechanism. Leukemia. 2016;30:484-91.

101. Yuraszeck T, Bartlett D, Singh I, Reed M, Pagano S, Zhu M. A quantitative systems pharmacology (QSP) model to assess the action of blinatumomab in NHL patients (pts). J Clin Oncol. 2016;34:e14511.

102. Duell J, Dittrich M, Bedke T, Mueller T, Eisele F, Rosenwald A, et al. Frequency of regulatory $T$ cells determines the outcome of the T-cellengaging antibody blinatumomab in patients with B-precursor ALL. Leukemia. 2017;31:2181-90.

103. Frey NV, Porter DL. Cytokine release syndrome with novel therapeutics for acute lymphoblastic leukemia. Hematology Am Soc Hematol Educ Program. 2016;2016:567-72

104. Stein AS, Schiller G, Benjamin R, Jia C, Zhang A, Zhu M, et al. Neurologic adverse events in patients with relapsed/refractory acute lymphoblastic leukemia treated with blinatumomab: management and mitigating factors. Ann Hematol. 2019;98:159-67.

105. Shimabukuro-Vornhagen A, Gödel P, Subklewe M, Stemmler HJ, Schlößer HA, Schlaak M, et al. Cytokine release syndrome. J Immunother Cancer. 2018;6:56.

106. Zheng P, Kros JM, Wang G. Elusive neurotoxicity in T cell-boosting anticancer therapies. Trends Immunol. 2019;40:274-8.

107. Klinger M, Zugmaier G, Nägele V, Goebeler M, Brandl C, Stelljes M, et al. Adhesion of T cells to endothelial cells facilitates blinatumomab-associated neurologic adverse events. Cancer Res. 2020;80:91-101.

108. Matasar MJ, Cheah CY, Yoon DH, Assouline SE, Bartlett NL, Ku M, et al. Subcutaneous mosunetuzumab in relapsed or refractory B-cell lymphoma: promising safety and encouraging efficacy in dose escalation cohorts. Blood. 2020;136:45-6.

109. Lesokhin AM, Levy MY, Dalovisio AP, Bahlis NJ, Solh M, Sebag M, et al. Preliminary safety, efficacy, pharmacokinetics, and pharmacodynamics of subcutaneously (SC) administered PF-06863135, a B-cell maturation antigen (BCMA)-CD3 bispecific antibody, in patients with relapsed/refractory multiple myeloma (RRMM). Blood. 2020;136:8-9.

110. Ribas A, Wolchok JD. Cancer immunotherapy using checkpoint blockade. Science. 2018;359:1350-5.

111. Köhnke T, Krupka C, Tischer J, Knösel T, Subklewe M. Increase of PD-L1 expressing B-precursor ALL cells in a patient resistant to the CD19/CD3bispecific T cell engager antibody blinatumomab. J Hematol Oncol. 2015;8:111.

112. Feucht J, Kayser S, Gorodezki D, Hamieh M, Döring M, Blaeschke F, et al. Tcell responses against CD19+ pediatric acute lymphoblastic leukemia mediated by bispecific T-cell engager (BiTE) are regulated contrarily by PDL1 and CD80/CD86 on leukemic blasts. Oncotarget. 2016;7:76902-19.

113. Cherkassky L, Morello A, Villena-Vargas J, Feng Y, Dimitrov DS, Jones DR, et al. Human CAR T cells with cell-intrinsic PD-1 checkpoint blockade resist tumor-mediated inhibition. J Clin Invest. 2016;126:3130-44.
114. Jackson CM, Choi J, Lim M. Mechanisms of immunotherapy resistance: lessons from glioblastoma. Nat Immunol. 2019;20:1100-9.

115. Ghiringhelli F, Larmonier N, Schmitt E, Parcellier A, Cathelin D, Garrido C, et al. CD4+CD25+ regulatory $T$ cells suppress tumor immunity but are sensitive to cyclophosphamide which allows immunotherapy of established tumors to be curative. Eur J Immunol. 2004;34:336-44.

116. Gabrilovich DI. Myeloid-derived suppressor cells. Cancer Immunol Res. 2017:5:3-8.

117. Perez C, Botta C, Zabaleta A, Puig N, Cedena M, Goicoechea I, et al. Immunogenomic identification and characterization of granulocytic myeloidderived suppressor cells in multiple myeloma. Blood. 2020;136:199-209.

118. Jabbour E, Düll J, Yilmaz M, Khoury JD, Ravandi F, Jain N, et al. Outcome of patients with relapsed/refractory acute lymphoblastic leukemia after blinatumomab failure: no change in the level of CD19 expression. Am J Hematol. 2018;93:371-4

119. Yu H, Sotillo E, Harrington C, Wertheim G, Paessler M, Maude SL, et al. Repeated loss of target surface antigen after immunotherapy in primary mediastinal large B cell lymphoma. Am J Hematol. 2017;92:E11-3.

120. Bukhari A, El Chaer F, Koka R, Singh Z, Hutnick E, Ruehle K, et al. Rapid relapse of large B-cell lymphoma after CD19 directed CAR-T-cell therapy due to CD-19 antigen loss. Am J Hematol. 2019;94:E273-5.

121. Braig F, Brandt $A$, Goebeler $M$, Tony $H$, Kurze $A$, Nollau $P$, et al. Resistance to anti-CD19/CD3 BiTE in acute lymphoblastic leukemia may be mediated by disrupted CD19 membrane trafficking. Blood. 2017;129:100-4.

122. Zhang Z, Chen X, Tian Y, Li F, Zhao X, Liu J, et al. Point mutation in CD19 facilitates immune escape of B cell lymphoma from CAR-T cell therapy. J Immunother Cancer. 2020;8:e001150.

123. Sotillo E, Barrett DM, Black KL, Bagashev A, Oldridge D, Wu G, et al. Convergence of acquired mutations and alternative splicing of CD19 enables resistance to CART-19 immunotherapy. Cancer Discov. 2015;5:1282-95.

124. Gardner R, Wu D, Cherian S, Fang M, Hanafi L, Finney O, et al. Acquisition of a CD19-negative myeloid phenotype allows immune escape of MLLrearranged B-ALL from CD19 CAR-T-cell therapy. Blood. 2016;127:2406-10.

125. Rayes A, McMasters RL, O'Brien MM. Lineage switch in MLL-rearranged infant leukemia following CD19-directed therapy. Pediatr Blood Cancer. 2016;63:1113-5.

126. Zoghbi A, Winkler B, Zur Stadt U, Müller I, Escherich G. Lineage switch under blinatumomab of a relapsed common ALL co-expressing myeloid markers without MLL rearrangement. Blood. 2016;128:5196.

127. Oberley MJ, Gaynon PS, Bhojwani D, Pulsipher MA, Gardner RA, Hiemenz MC, et al. Myeloid lineage switch following chimeric antigen receptor T-cell therapy in a patient with TCF3-ZNF384 fusion-positive B-lymphoblastic leukemia. Pediatr Blood Cancer. 2018;65:e27265.

128. He RR, Nayer Z, Hogan M, Cuevo RS, Woodward K, Heyer D, et al. Immunotherapy- (blinatumomab-) related lineage switch of KMT2A/AFF1 rearranged B-lymphoblastic leukemia into acute myeloid leukemia/myeloid sarcoma and subsequently into B/myeloid mixed phenotype acute leukemia. Case Rep Hematol. 2019;2019:7394619.

129. Ruella M, Barrett DM, Kenderian SS, Shestova O, Hofmann TJ, Perazzelli J, et al. Dual CD19 and CD123 targeting prevents antigen-loss relapses after CD19-directed immunotherapies. J Clin Invest. 2016;126:3814-26.

130. Dai H, Wu Z, Jia H, Tong C, Guo Y, Ti D, et al. Bispecific CAR-T cells targeting both CD19 and CD22 for therapy of adults with relapsed or refractory B cell acute lymphoblastic leukemia. J Hematol Oncol. 2020;13:30.

131. Baeuerle PA, Reinhardt C. Bispecific T-cell engaging antibodies for cancer therapy. Cancer Res. 2009;69:4941-4.

132. Lorenczewski G, Friedrich M, Kischel R, Dahlhoff C, Anlahr J, Balazs M, et al. Generation of a half-life extended anti-CD19 BiTE ${ }^{\circledR}$ antibody construct compatible with once-weekly dosing for treatment of CD19-positive malignancies. Blood. 2017;130:2815.

133. Marion S, Anthony S, Roland BW, Ravi B, Andrew HW, David R, et al. Updated results from a phase 1 first-in-human dose-escalation study of AMG 673, a novel anti-CD33/CD3 BiTE ${ }^{\oplus}$ (bispecific T-cell engager) molecule in patients with relapsed/refractory (R/R) acute myeloid leukemia (AML). EHA Library. 2020;294466:EP548.

134. Herrmann M, Krupka C, Deiser K, Lindl B, Mocikat R, Metzeler KH, et al. Development of a bifunctional checkpoint inhibitory T cell engager (CiTE) to reverse adaptive immune escape in AML. Blood. 2018;132:4069.

135. Schwartz RH. A cell culture model for T lymphocyte clonal anergy. Science. 1990;248:1349-56

136. Liu R, Jiang W, Yang M, Guo H, Zhang Y, Wang J, et al. Efficient inhibition of human B-cell lymphoma in SCID mice by synergistic antitumor effect of 
human 4-1BB ligand/anti-CD20 fusion proteins and anti-CD3/anti-CD20 diabodies. J Immunother. 2010;33:500-9.

137. Arndt C, Feldmann A, von Bonin M, Cartellieri M, Ewen E, Koristka S, et al. Costimulation improves the killing capability of T cells redirected to tumor cells expressing low levels of CD33: description of a novel modular targeting system. Leukemia. 2014;28:59-69.

138. Laszlo GS, Gudgeon CJ, Harrington KH, Walter RB. T-cell ligands modulate the cytolytic activity of the CD33/CD3 BiTE antibody construct, AMG 330. Blood Cancer J. 2015;5:e340.

139. Correnti CE, Laszlo GS, de van der Schueren WJ, Godwin CD, Bandaranayake A, Busch MA, et al. Simultaneous multiple interaction T-cell engaging (SMIT E) bispecific antibodies overcome bispecific T-cell engager (BiTE) resistance via CD28 co-stimulation. Leukemia. 2018;32:1239-43.

140. Choi BD, Yu X, Castano AP, Bouffard AA, Schmidts A, Larson RC, et al. CAR-T cells secreting BiTEs circumvent antigen escape without detectable toxicity. Nat Biotechnol. 2019;37:1049-58.

141. Guo ZS, Lotze MT, Zhu Z, Storkus WJ, Song X. Bi- and tri-specific T cell engager-armed oncolytic viruses: next-generation cancer immunotherapy. Biomedicines. 2020;8:204

142. Scott EM, Jacobus EJ, Lyons B, Frost S, Freedman JD, Dyer A, et al. Bi- and tri-valent $T$ cell engagers deplete tumour-associated macrophages in cancer patient samples. J Immunother Cancer. 2019;7:320.

143. Freedman JD, Duffy MR, Lei-Rossmann J, Muntzer A, Scott EM, Hagel J, et al. An oncolytic virus expressing a T-cell engager simultaneously targets cancer and immunosuppressive stromal cells. Cancer Res. 2018;78:6852-65.

144. Porter CE, Rosewell Shaw A, Jung Y, Yip T, Castro PD, Sandulache VC, et al. Oncolytic adenovirus armed with BiTE, cytokine, and checkpoint inhibitor enables CAR T cells to control the growth of heterogeneous tumors. Mol Ther. 2020;28:1251-62.

145. Klupsch K, Baeriswyl V, Scholz R, Dannenberg J, Santimaria R, Senn D, et al. Abstract 1787: COVA4231, a potent CD3/CD33 bispecific FynomAb with IgG-like pharmacokinetics for the treatment of acute myeloid leukemia. Cancer Res. 2018;78:1787.

146. Liu L, Lam CK, Long V, Widjaja L, Yang Y, Li H, et al. MGD011, A CD19 x CD3 dual-affinity retargeting bi-specific molecule incorporating extended circulating half-life for the treatment of B-cell malignancies. Clin Cancer Res. 2017;23:1506-18.

147. Mayes P, Tacken P, Wang S, Loo PV, Condamine T, Maaden HVD, et al. Abstract 539: a bispecific Fc-silenced IgG1 antibody (MCLA-145) requires PD-L1 binding to activate CD137. Cancer Res. 2019;79:539.

148. Seckinger A, Delgado JA, Moser S, Moreno L, Neuber B, Grab A, et al. Target expression, generation, preclinical activity, and pharmacokinetics of the BCMA-T cell bispecific antibody EM801 for multiple myeloma treatment. Cancer Cell. 2017;31:396-410

149. Schlothauer T, Herter S, Koller CF, Grau-Richards S, Steinhart V, Spick C, et al. Novel human IgG1 and lgG4 Fc-engineered antibodies with completely abolished immune effector functions. Protein Eng Des Sel. 2016;29:457-66.

150. Chornoguz O, Leettola CN, Leander K, Brosnan K, Emmell E, Chiu ML, et al. Characterization of a novel bispecific antibody that activates $T$ cells in vitro and slows tumor growth in vivo. Monoclon Antib Immunodiagn Immunother. 2019:38:242-54

151. Engelberts PJ, Hiemstra $H$, de Jong B, Schuurhuis DH, Meesters J, Beltran Hernandez I, et al. DuoBody-CD3xCD20 induces potent T-cell-mediated killing of malignant B cells in preclinical models and provides opportunities for subcutaneous dosing. Ebiomedicine. 2020;52:102625.

152. Wang L, Hoseini SS, Xu H, Ponomarev V, Cheung N. Silencing fc domains in T cell-engaging bispecific antibodies improves T-cell trafficking and antitumor potency. Cancer Immunol Res. 2019;7:2013-24.

153. Veglia F, Perego M, Gabrilovich D. Myeloid-derived suppressor cells coming of age. Nat Immunol. 2018;19:108-19.

154. Wu L, Seung E, Xu L, Rao E, Lord DM, Wei RR, et al. Trispecific antibodies enhance the therapeutic efficacy of tumor-directed $T$ cells through $T$ cell receptor co-stimulation. Nat Can. 2020;1:86-98.

155. Seftel MD. Hyper-CVAD: a regimen for all seasons. Lancet Haematol. 2020;7: e501-2.

156. Richard-Carpentier G, Kantarjian HM, Short NJ, Ravandi F, Ferrajoli A, Schroeder HM, et al. Updated results from the phase II study of hyper-CVAD in sequential combination with blinatumomab in newly diagnosed adults with B-cell acute lymphoblastic leukemia (B-ALL). Blood. 2019;134:3807.

157. Fleming S, Venn N, Reynolds J, Nguyen U, Kwan J, Moore J, et al. Preliminary minimal residual disease analysis of the Australasian Leukaemia
\& Lymphoma Group (ALLG) ALL8 study of front-line blinatumomab with chemotherapy in adults with Ph negative B-cell acute lymphoblastic leukaemia. Blood. 2019;134:1300.

158. Short NJ, Kantarjian HM, Ravandi F, Huang X, Ferrajoli A, Kadia TM, et al. Hyper-CVAD and sequential blinatumomab in adults with newly diagnosed Philadelphia chromosome-negative B-cell acute lymphoblastic leukemia: results from a phase II study. Blood. 2020;136:9-11.

159. Katz DA, Chu MP, David KA, Thieblemont C, Morley NJ, Khan SS, et al. Openlabel, phase 2 study of blinatumomab after first-line rituximabchemotherapy in adults with newly diagnosed, high-risk diffuse large B-cell lymphoma. Blood. 2019;134:4077.

160. Sasaki K, Kantarjian HM, Ravandi F, Short NJ, Kebriaei P, Huang X, et al. Sequential combination of inotuzumab ozogamicin ( $\mathrm{InO})$ with low-intensity chemotherapy (mini-hyper-CVD) with or without blinatumomab is highly effective in patients (pts) with Philadelphia chromosome-negative acute lymphoblastic leukemia (ALL) in first relapse. Blood. 2019;134:3806.

161. Sasaki K, Kantarjian HM, Ravandi F, Short NJ, Kebriaei P, Huang X, et al. Long-term follow-up of the combination of low-intensity chemotherapy plus inotuzumab ozogamicin with or without blinatumomab in patients with relapsed-refractory Philadelphia chromosome-negative acute lymphoblastic leukemia: a phase 2 trial. Blood. 2020;136:40-2.

162. McCloskey JK, Gagnon J, McCabe T, Charlon J, Wang S, Fan R, et al. Blinatumomab in combination with tyrosine kinase inhibitors safely and effectively induces rapid, deep, and durable molecular responses in relapsed and refractory Philadelphia positive acute leukemias. Blood. 2019;134:3812.

163. Assi R, Kantarjian H, Short NJ, Daver N, Takahashi K, Garcia-Manero G, et al. Safety and efficacy of blinatumomab in combination with a tyrosine kinase inhibitor for the treatment of relapsed Philadelphia chromosome-positive leukemia. Clin Lymphoma Myeloma Leuk. 2017;17:897-901.

164. Couturier M, Thomas X, Huguet F, Berthon C, Simand C, Hicheri Y, et al. Blinatumomab + ponatinib for relapsed Ph1-positive acute lymphoblastic leukemia: the French experience. Blood. 2018;132:4014.

165. Chiaretti S, Bassan R, Vitale A, Elia L, Piciocchi A, Puzzolo C, et al. Dasatinibblinatumomab combination for the front-line treatment of adult Ph+ ALL patients. Updated results of the gimema LAL2116 D-Alba trial. Blood. 2019; $134: 740$.

166. Campos-Cabrera G, Vega-Tapia N, Campos-Cabrera V, Campos-Cabrera S, Campos-Villagomez J, Mendez-Garcia E. Blinatumomab and venetoclax for minimal residual disease relapse in acute lymphoblastic leukemia. Blood. 2019;134:5128.

167. Webster J, Luskin MR, Prince GT, DeZern AE, DeAngelo DJ, Levis MJ, et al. Blinatumomab in combination with immune checkpoint inhibitors of PD-1 and CTLA-4 in adult patients with relapsed/refractory (R/R) CD19 positive Bcell acute lymphoblastic leukemia (ALL): preliminary results of a phase I study. Blood. 2018;132:557.

168. Schwartz M, Damon LE, Jeyakumar D, Costello CL, Tzachanis D, Schiller GJ, et al. Blinatumomab in combination with pembrolizumab is safe for adults with relapsed or refractory B-lineage acute lymphoblastic leukemia: University of California Hematologic Malignancies Consortium Study 1504. Blood. 2019;134:3880.

169. Buccheri S, Guggino G, Caccamo N, Li DP, Dieli F. Efficacy and safety of gammadeltaT cell-based tumor immunotherapy: a meta-analysis. J Biol Regul Homeost Agents. 2014;28:81-90.

170. Sebestyen Z, Prinz I, Dechanet-Merville J, Silva-Santos B, Kuball J. Translating gammadelta (gammadelta) T cells and their receptors into cancer cell therapies. Nat Rev Drug Discov. 2020;19:169-84.

171. de Bruin RCG, Veluchamy JP, Lougheed SM, Schneiders FL, Lopez-Lastra S, Lameris $R$, et al. A bispecific nanobody approach to leverage the potent and widely applicable tumor cytolytic capacity of Vy9V82-T cells. Oncoimmunology. 2017;7:e1375641.

172. Kuhns MS, Badgandi HB. Piecing together the family portrait of TCR-CD3 complexes. Immunol Rev. 2012;250:120-43.

173. Bachiller M, Battram AM, Perez-Amill L, Martín-Antonio B. Natural killer cells in immunotherapy: are we nearly there? Cancers. 2020;12:3139.

174. Schmohl JU, Felices M, Taras E, Miller JS, Vallera DA. Enhanced ADCC and NK cell activation of an anticarcinoma bispecific antibody by genetic insertion of a modified IL-15 cross-linker. Mol Ther. 2016;24:1312-22.

175. Vallera DA, Felices M, McElmurry R, McCullar V, Zhou X, Schmohl JU, et al. IL15 trispecific killer engagers (TriKE) make natural killer cells specific to CD33+ targets while also inducing persistence, in vivo expansion, and enhanced function. Clin Cancer Res. 2016;22:3440-50. 
176. Gauthier L, Morel A, Anceriz N, Rossi B, Blanchard-Alvarez A, Grondin G, et al. Multifunctional natural killer cell engagers targeting NKp46 trigger protective tumor immunity. Cell. 2019;177:1701-1713.e16.

177. Heczey A, Courtney AN, Montalbano A, Robinson S, Liu K, Li M, et al. AntiGD2 CAR-NKT cells in patients with relapsed or refractory neuroblastoma: an interim analysis. Nat Med. 2020;26:1686-90.

178. Klichinsky M, Ruella M, Shestova O, Lu XM, Best A, Zeeman M, et al. Human chimeric antigen receptor macrophages for cancer immunotherapy. Nat Biotechnol. 2020;38:947-53.

\section{Publisher's Note}

Springer Nature remains neutral with regard to jurisdictional claims in published maps and institutional affiliations.

Ready to submit your research? Choose BMC and benefit from:

- fast, convenient online submission

- thorough peer review by experienced researchers in your field

- rapid publication on acceptance

- support for research data, including large and complex data types

- gold Open Access which fosters wider collaboration and increased citations

- maximum visibility for your research: over $100 \mathrm{M}$ website views per year

At $\mathrm{BMC}$, research is always in progress.

Learn more biomedcentral.com/submissions 